\title{
Linear A du-pu2-re, Hittite tabarna and their alleged relatives revisited $^{*}$
}

This article intends to be a comprehensive reassessment of a previous hypothesis connecting the Linear A sequence $d u-p u_{2}$-re and the Hittite royal title t/labarna-, as well as a series of Anatolian words, toponyms and personal names allegedly related to the latter and belonging to the semantic sphere of power. In the course of this survey, several Anatolian onomastic elements, mostly dated to the $1^{\text {st }}$ millennium BCE, are disconnected from the Minoan sequence and the Hittite title, and receive new explanations (with various levels of security) in the framework of the Luwic (IE) languages. Likewise, I separate Labranios (a Cypriot epithet of Zeus) from Hittite labarna- and argue instead for the old theory that it is an adaptation of the Phoenician name of Mount Lebanon. The conclusion of this reassessment is that, while there may have been a Luwian noun *tapara- 'rule', there are no independent grounds for linking any Anatolian material to Minoan $d u-p u_{2}$-re and no basis for assuming the latter meant 'master' (or similar).

Keywords: Linear A, Tabarna, Labarna, Luwic languages, Anatolian onomastics, Cilician names.

\section{Introduction}

Although the language of Linear A (LA), the logo-syllabic script of Minoan Crete, still eludes interpretation, the writing system itself cannot be considered wholly undeciphered. Decades of scholarship have shown that a significant number of syllabograms have phonetic values analogous to their Linear B (LB) counterparts. Particularly, through a set of independent contextual tests Duhoux (1989) has proved this to be the case with at least 30 syllabograms. ${ }^{1}$ Inevitably, since LB is the product of an adaptation of LA to another language (Mycenaean Greek), which surely possessed a different phonemic inventory, we can hardly expect all phonetic values to be exact matches. They can, nevertheless, act as guiding phonetic approximations.

In a previous work (Valério 2007), I have dealt with a LA sequence which in this way reads $d u-p u_{2}-r e$. It is found self-standing once (KO Za 1$)$ and elsewhere in compounds, namely

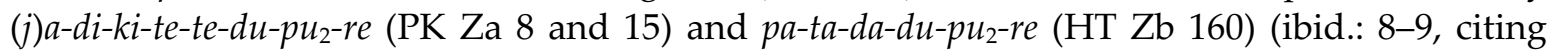

\footnotetext{
* The content of this article derives mainly from a presentation made at the $1^{\text {st }}$ session of the workshop 'Luwic' Dialects: Inheritance and Diffusion (University of Barcelona, October 23, 2013). The final text benefits from various comments, references and suggestions by I.-X. Adiego (U. Barcelona), A. Kassian (Russian Academy of Sciences), C. Melchert (UCLA), I. Yakubovich (U. Marburg) and J. G. Younger (U. Kansas). Thanks are also owed to R. Oreshko (U. Hamburg) for sending me a copy of his recent work. As usual, the responsibility for the views here contained, as well as any mistakes and shortcomings, is mine alone.

${ }^{1}$ These included a survey of the positional frequency of the suspected vowel (V) syllabograms, and listing sign alternations in LA-B pairs of sequences and within LA itself. Duhoux was cautious about the results: he considered different levels of security for each of the phonetic values depending on how many contextual tests confirmed them.
} 
GORILA). I hypothesized that the compound (j)a-di-ki-te-te-du-pu $-r e$ was to be segmented (j) $a=d i-k i-t e-t e=d u-p u_{2}-r e$ and signified a periphrastic divine name: '(to?) the Diktaian Master', or similar. Thus, $d u-p u_{2}-r e$ would be the Minoan word for 'master, lord'. The basis for this interpretation included three morphophonological and contextual facts: (1) the existence of a Minoan stem $d u-p u_{2}-r-\left(>d a-p u_{2}-r-\right)$, which I linked with LB da-pu(2)-ri-to- = alphabetical

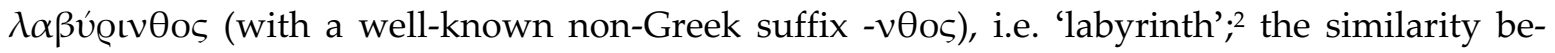
tween $(j) a=d i-k i$-te-te $=$ and the name of Mount Dikte, aided by the fact the compounds with this string are limited to stone libation tables found at or near the Minoan peak sanctuary of Petsofas (near Palaikastro, East Crete), which later in the Archaic period was devoted precisely to to Diktaian Zeus (i.e. Zeus born on Mount Dikte); beyond phonetic resemblance, this supported the interpretation of (j)a-di-ki-te-te $e^{\underline{o}}$ as 'Diktaian'; (3) the attestation of LB di-ka-ta-jo di-we 'Diktaian Zeus' at Knossos, showing a Late Bronze Age Cretan background for this deity. However, on the side of semantics, the grounds to propose 'master' as the meaning of $d u-p u_{2}-r e$

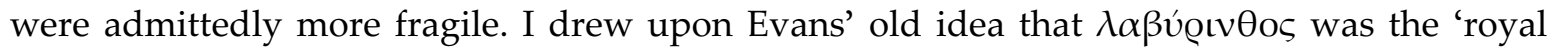
palace' of Knossos (see \$2) and the presumable similarity of $d a-p u(2)-r-/ \lambda \alpha \beta u ́ Q-$ to one of the titles of the Hittite kings, tabarna-/labarna-, as well as a series of words and onomastic elements from Anatolia and Cyprus presumably related to the latter and belonging to the sphere of (human and divine) power.

In this I followed mainly the work of Yakubovich (2002) on Hitt. t/labarna- and its connections. The title has been among the most hotly debated items of the Hittite vocabulary, with contending interpretations of its etymology, Indo-European (IE) and non-IE, including proposals of a traveling contact word (Wanderwort) (see \$10). Although at present the author thinks it is impossible to quantify the plausibility of the competing IE and non-IE hypotheses (pers. comm.), Yakubovich (2002) contains the most extensive argument favorable to the migrating word hypothesis, which provided the basis for the interpretation in Valério (2007). Starting with the Luwo-Hittite form (:)tapar- 'to rule', long thought to be related to Hitt. t/labarna-, Yakubovich compiled a dossier of possible regional connections:

1.1) Luwo-Hitt. tapar(r)iya- 'to rule' and derivatives;

1.2) Hieroglyphic Luwian LEPUS+ra/i-i(a)- 'authority' and derivatives;

1.3) The Hellenistic Cilician personal names T $\beta \varepsilon \varrho \alpha \sigma \eta \tau \alpha \varsigma$ and T $\beta \varepsilon \varrho \eta \mu \omega \sigma \iota \varsigma$ (presumably reflecting ${ }^{*}$ Tapara-zita/i and ${ }^{*}$ Tapara-muwa+zi, respectively)

1.4) The Lycian personal name Dapara- $=\Lambda \mathrm{A} \Pi \mathrm{APA} \Sigma$;

1.5) Labranios ( $\triangle \mathrm{ABPANIO} \Sigma$ ), an epithet of Zeus in Cyprus;

2 An identical suggestion (unknown to me until very recently) was made by Billigmeier (1989), but unfortunately it was limited to an abstract, with no follow-up paper ever being published (thanks are owed to B. Davis and J. Younger for helping me locate this reference). My own argument (Valério 2007: 7-8) was based on the following: LA $d u-p u_{2}-r e$ is reminiscent of LB $d u-p u_{2}-r a-z o(K N$ V[3] 419.1) and da-pu-ra-zo (EL 1 1.2), two non-Greek personal names or, rather, two variants of the same name. The $\mathrm{Cu}-\mathrm{CV}-/ \mathrm{Ca}-\mathrm{CV}$ - alternation is seen in two wellknown LA-B pairs: LA ku-pa $-n u$ (HT 1, 3, 42, 49, 88, 117, 122) / ku-pa-na-tu (HT 119.3), attested in likely Minoan lists of persons, and the non-Greek personal names ka-pa-no (KN As[2] 1516.16) / ka-pa-na-to (KN Df 1219) in LB tablets from Knossos. Since $-z o$ is a common ending of non-Greek names in the LB records from Knossos, it seems that the names above and LB $d a-p u(2)-r i$-to- contain a Minoan element $d u-p u_{2}-r^{\circ}$. The most plausible explanation for the vocalism is that of Davis (2014: 242-243): $d u-p u_{2}-r$ - reflects Min. /DǔPúr-/ with an unaccented short /u/ that tended to be centralized to a schwa, whence /DəPúr-/, transcribed in LB as da-pu- $-r-$, with $a$ (I use "D" and "P" to represent what in my opinion are undetermined dental and labial obstruents). The LA texts are cited according to GORILA and those of LB follow DocMyc². 
1.6) The epithet of Zeus Labraundos ( $\Lambda \alpha \dot{\beta} \mathrm{\varrho} \alpha v v \delta o \varsigma)$, at the city of Labraunda, in Caria (with several variant spellings: $\Lambda$ ABPA $\Upsilon N \triangle \mathrm{O} \Sigma \Lambda \mathrm{ABPAI} \Upsilon \mathrm{N} \triangle \mathrm{O} \Sigma ; \Lambda \mathrm{ABPAA} \Upsilon \mathrm{N} \Delta \mathrm{O} \Sigma$; $\Lambda \mathrm{ABPAIN} \triangle \mathrm{O} \Sigma ; \Lambda \mathrm{ABPAEN} \Delta \mathrm{O} \Sigma ; \Lambda \alpha \dot{\beta} \mathrm{O} \alpha \nu \delta \mathrm{o} \varsigma ; \Lambda \mathrm{ABPEN} \Delta \mathrm{O} \Sigma$; and later $\Lambda \alpha \beta \mathrm{O} \alpha[v] \delta \varepsilon ́ v \varsigma)$

1.7) LB $d a-p u / p u_{2}-r i-t o-=$ alphabetical Greek $\lambda \alpha \beta u ́ \varrho ı v \theta o s$

At the time, the author suggested that these forms were all derivatives of migrating South

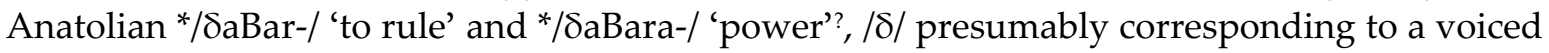
coronal fricative /ð/. Thus, Lyc. Dapara would be a direct product of */SaBara-/, while the Luwian forms would have undergone the development $* / \delta a B a r-/>* /$ taBar- $/$. The lambdacist transcription of Dapara as Grk. $\Lambda \alpha \pi \alpha \varrho \alpha \varsigma$ would reflect this alien / $/ /$, as would the $d \sim \lambda$ alternation in $d a-p u(2)-r i$-to-/ $\lambda \alpha \beta u ́ \rho ı \theta o s$ and the varying t/labarna-.

In Valério (2007), I proposed this virtual */ठaBar-/ to be related also to LA $d u-p u_{2}-r e$, but to help explaining its vocalism, I augmented the dossier of possible Anatolian relatives to include:

1.8) A set of Carian personal names with the alleged element -DUbr- (where D apparently corresponded to either Car. $\delta$ or $t \rightarrow$ Grk. $\delta$, and U seemed to match Car. $w$, now transliterated $\dot{y}=$ Grk. $v$ ), including the alleged equivalences of the names ksatýbr $\rightarrow$ $\Xi \alpha v \delta v \beta \varepsilon \varrho \iota \varsigma$ and smdýbrs $\rightarrow \mathrm{Z} \varepsilon \mathrm{Q} \mu \varepsilon \delta v \beta \varepsilon \varrho o s$.

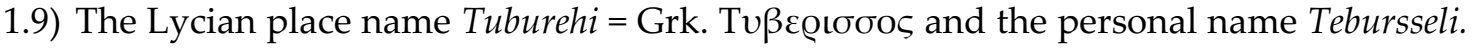

A reassessment of my interpretation is now necessary, partly because of intrinsic problems (it admittedly depends on a number of undemonstrated connections) and partly because of its ramifications for the study of the language of LA. Given their phonological shape, the Carian names were one of the cornerstones of the hypothesis, but at the time I put it on paper, I had not yet had the opportunity to study comprehensively the entire dossier (which is gathered and discussed in Adiego 2007). In the meantime, the interpretation of LA $d u-p u_{2}-r e$ in Valério (2007) has gained some acceptance, ${ }^{3}$ and its alleged ties to Hitt. t/labarna- and Lyc. dapara/ $\Lambda \alpha \pi \alpha \varrho \alpha \varsigma$ are now part of an argument by Davis (2014: 193-215) that the LA $d$ series transcribed a "phoneme $/ \theta /$ that was realized in Minoan speech as allophones [ð] and [ $\theta]$ ". In what follows, I will revisit the whole dossier.

\section{2. (Non-)Greek $\lambda \alpha \beta u ́ \varrho ı v \theta o s$ and Carian $\Lambda \alpha \beta \varrho \alpha ́ v v \delta \alpha$}

The theories connecting $\lambda \alpha \beta u ́ \varrho ı v \theta o \varsigma$ and the Carian city Labraunda $(\Lambda \alpha \beta \varrho \alpha ́ v v \delta \alpha)$ can be traced back to Plutarch's (Greek Questions 45, 2.302a) explanation of the local epithet of Zeus, Labrandeus (sic), as a derivative of $\lambda \alpha \dot{\beta} \rho u s$, an alleged Lydian word for 'axe'. The Lydian word may have existed, but there is a chance the account of the ancient author owes to a folk etymology formulated at the end of the $1^{\text {st }}$ millennium BCE, since Zeus Labraundos was characteristically depicted holding a double-axe in Achaemenid coins from Caria (Yakubovich 2002: 106-107, fn. 36.). At the end of the $19^{\text {th }}$ century, Mayer and Kretschmer (apud Kretschmer 1896: 404) came up with the idea that Labraundos corresponded to "Cretan" $\lambda \alpha \beta$ @́ notion emerged in connection with another theory by Kretschmer, namely that the toponymic suffixes $-v \theta 0 \varsigma$ (Aegean) and $-v \delta \alpha$ (Anatolia) are cognate and ensue from a Pre-Greek "substrate" language spoken on both sides of the Aegean Sea in prehistoric times. This idea is far

\footnotetext{
${ }^{3}$ See Younger (2011: 170, fn. 66) and Davis (2013: 42, 44; 2014).
} 
from demonstrated, ${ }^{4}$ but the crucial issue is not even the suffix, but the base morphemes, which require us to equate $\lambda \alpha \beta v ́ \mathrm{\varrho}(\mathrm{l})$ - and $\Lambda \alpha \beta \mathrm{Q} \alpha(v)$ - (with all its variants; see $\S 1$ ). Already Kretschmer (1896: 404) had to do great phonological gymnastics and conjecture for both placenames a common preform ${ }^{*} \Lambda \alpha \beta \rho \alpha v v v \theta o s$.

We know now that this is far from the reality: the Late Bronze Age form of $\lambda \alpha \beta$ voเv $\theta$ os was $d a-p u(2)-r i-t o-$, reflecting most likely /dap ${ }^{\mathrm{h}}$ úrint $^{\mathrm{h}} \mathrm{os} / .^{5} \mathrm{In}$ fact, it is often neglected that the pair is not synchronic: $\lambda \alpha \beta$ v́ centuries separate it from its Mycenaean predecessor. In LB itself there are no examples whatsoever of words interchanging LB $d=/ \mathrm{d} /$ and $r=/ 1 /$, which means there is no support for assuming Myc. ${ }^{*} /$ dap $^{\mathrm{h}}$ úrint $^{\mathrm{h}}$ os/ $\sim$ */lap ${ }^{\mathrm{h}}$ úrint ${ }^{\mathrm{h}}$ os/ and, more significantly, no basis for Lejeune's old idea that the $d \sim \lambda$ spellings reflect Greek attempts to render a foreign sound. More likely,

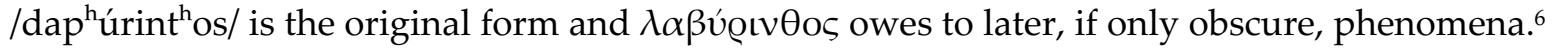

Finally, in his renowned work on the Knossos palace, Evans (1921: 6) picked up on the (unprovable) suggestions of Mayer and Kretschmer and further claimed the double axe of

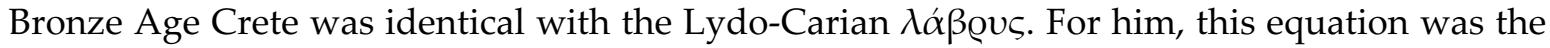
"key" to understand both Labraundos and the "Labyrinth", which to his mind were to be "identified with the palace sanctuary of Knossos". Such etymological speculations constitute the historiographical roots of the interpretation of Grk. $\lambda \alpha \beta v$ @ıv $\theta$ o $\varsigma$ as 'royal palace' (see §1). The fact remains that in its first attestation $\lambda \alpha \beta v$ @ıv $\theta$ o $\varsigma$ was used by Herodotus (2.148) to refer to a vast, partially-underground Egyptian mortuary complex, so not only we have no basis to infer 'palace' was its original sense, but it is actually the case that other meanings, such as 'hypogeum', would explain better the earliest uses of the word (see Sarullo 2008).

\section{Cypriot Greek $\Lambda \mathrm{ABPANIO \Sigma}$}

In Cyprus, a cult to Zeus Labranios ( $\triangle \mathrm{ABPANIO} \Sigma$ ) is known through a dozen of ex-votos from the Roman period (late $2^{\text {nd }}-4^{\mathrm{t}^{\mathrm{h}}}$ century), found at Fasoúla, $10 \mathrm{~km}$ to the north of Amathus, and at Chandría, to the north of Fasoúla in the Troodos Mountains (Mitford 1961: 111, nos. 12-13).

Yakubovich (2002: 104-105; see also 2009a: 268) advanced tentatively a connection with labarna-. In a way, this echoed a theory first expounded by Hall (1885 [1883]: clxviii-clxix), who compared Zeus Labranios to Zeus Labraundos (see §2). According to Hall, the cult of Zeus

${ }^{4}$ For recent discussions see de Hoz (2004) and Yakubovich (2009b: 9-11).

${ }^{5}$ Chadwick has pointed out that " $p u_{2}=b u$ is ... remarkable" (Ventris and Chadwick 1973: 538), and indeed the pronunciation of the interchanging $p u=/ p u, p^{h} \mathrm{u} /$ and $p u_{2} / \mathrm{p}^{\mathrm{h}} \mathrm{u} /$ ought to be $/ \mathrm{p}^{\mathrm{h}} \mathrm{u} /$. Although descriptions of the phonological system of Myc. Greek routinely include a phoneme /b/, they overlook the fact that there are no uncontroversial examples of $/ b /$ in native Mycenaean words; the phoneme was absent or near absent from the language, a situation which was inherited from PIE (see Thompson 2005).

${ }^{6} \mathrm{LB} d>$ alphabetical $\lambda$ shift(?) is reminiscent of two Pamphylian glosses in Hesychius, who notes that stan-

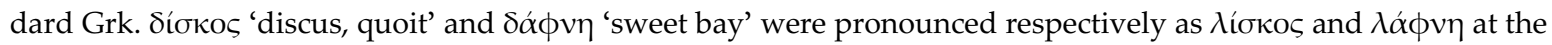
city of Perge. As we will see in $\S 8$ and $\S 10,1^{\text {st }}$ millennium Anatolian languages like Lydian and Lycian lacked initial /d-/, which was replaced with /l-/ in loanwords (at least in Lydian). This suggests that Pergaean $\lambda$ íoko 5 and $\lambda \alpha ́ \phi v \eta$ may have been the pronunciations of local Anatolians who spoke Greek as a second language. Since $\lambda \alpha \beta u ́ \varrho ı v \theta o \varsigma$ first appears in the work of Herodotus, a native of Halicarnassus (Caria), perhaps its lambdacism owes to similar reasons. As regards LB $p\left({ }_{2}\right)=/ \mathrm{p}^{\mathrm{h}} /$ vs. alph. $\beta$ (see fn. 5), it is tempting to speculate that $/ \mathrm{dap}^{\mathrm{h}}$ úrint $^{\mathrm{h}} \mathrm{os} / \mathrm{co}^{-}$ existed with $* /$ dawúrint ${ }^{\mathrm{h}}$ os/ owing to different Greek strategies to render a foreign voiceless labial fricative

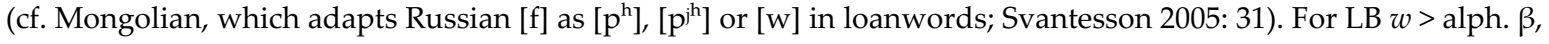

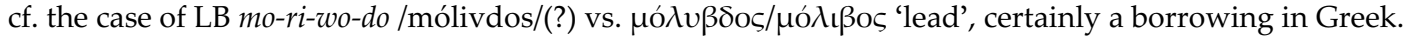


Labraundos was taken by Carian settlers to Cyprus, where the toponymic epithet developed into Labranios through multiple and irregular sound changes.

A more economical explanation arose not much later from the pen of Ohnefalsch-Richter (1893: 220, 229), who equated Zeus Labranios with Phoenician b\&l lbnn 'Ba'al of Lebanon', 7 a deity worshiped in Cyprus in Pre-Roman times. Syncretisms between Greek Zeus and Semitic Ba'al are far from unseen and this one was later accepted by Mitford (1961: 111, 143), who worked extensively on Cypriot epigraphy, as well as Lipiński (1995: 306-307), a Semiticist.

At first sight, the inexact phonological match between lbnn and Labranios might seem to deter the identification. Credit is due to Lipiński (ibid.) for his comparison of H. Luw. (MONS) La-pa+ra/i-na-, most probably 'Mt. Lebanon' (see Hawkins 2000: 414). */Labrana/ and */Labarna/ are both possible readings, but the former is more likely in the light of Hitt. Lablana, Hurr. Lablahhi 'from/of Lebanon' (<*Lablan=hi), Ugarit Akkadian [H]UR.S[AG la]-ab-la-na and Neo-Assyrian Akkadian Labnāna (see Del Olmo and Sanmartín 2003: 491). However, based on the Luwian form, Lipiński maintained that Labranios 'of Mt. Lebanon' was ultimately of Anatolian origin. This explanation is as implausible in historical terms as it is unnecessary. Greek and Phoenician-speaking communities coexisted in Iron Age Cyprus, ${ }^{8}$ so Phoenician can be taken as the direct source of Labranios. As for H. Luw. La-pa+ra/i-na-/Labrana-/, it may be just the outcome of the characteristic Luwian $l>r$ "flapping" in a previous form *Lablana-, cognate with the abovementioned Hittite name of Mt. Lebanon. ${ }^{9}$

We only need to account for the phonological details of the Greek adaptation. In the Semitic languages the oronym contains /bn/, but since synchronically this cluster never occurs in native Greek words, ${ }^{*} \Lambda \alpha \beta v \alpha v$ - would be impossible as the Hellenic adaptation of Phoen. Lbnn. Thus, $\Lambda \alpha \beta \mathrm{Q} \alpha v$ - with /br/ must have been the alternative. Finally, the ending -los may correspond to a well-attested ancient Cypriot Greek genitive suffix that occurs in ethnics (cf. e.g. se-la-mi-ni-o-se /Selaminios/ 'from Salamis') as well as in divine epiclesis (Egetmeyer 2010: 253-254, 260-261).

\section{Alleged Carian names with *-DUbr}

Now that LA $d u-p u_{2}-r e$ and LB $d a-p u(2)$-ri-to- have been disconnected from the Carian placename Labraunda, we need to reassess the dossier of Carian names that was crucial to the interpretation of the Minoan form. As stated above, I will now discuss all names listed in Adiego (2007) that could in theory contain a -DUbr element:

5.1) ardybyrś (E.Me 52)

5.2) ardybyrś (E.Me 52)

5.3) dtýbr (E.Th 2)

5.4) dýbr (E.Th 5)

5.5) kśatýbr (E.Th 2)

5.6) kudtubr (E.Th 9)

5.7) smó́brs (C.Ha 1)

7 This form is attested in an inscribed bronze bowl (KAI 31; cf. Masson and Sznycer 1972: 77-78).

${ }^{8}$ For a recent survey of the evidence for linguistic contact between Phoenician and Greek in Cyprus, see, e.g. Egetmeyer (2010).

9 The consonantal divergence between Hurrian/Hittite/Ugarit Akkadian lbln- and Assyrian/Phoenician lbnn is best explained by a dissimilatory or assimilatory process involving this chain of sonants. I thank A. Kassian for suggesting this solution. 
Two facts are relevant. First, the names remain opaque, and there is not the slightest hint of a connection to the semantics of power. Second, our present knowledge of Carian historical phonology does not suggest that Carian $y, y$ or $u$ can have the same source of Luwian $a$, the implication being that any connection to Luw. tapar- 'to rule' cannot go back to a Proto-Luwic stage; ${ }^{10}$ we would rather be forced to assume that ${ }^{*}$-DUbr was a late borrowing in Carian, and that, like Minoan, it had differences in vocalism. Before considering borrowings, however, I believe the more recommendable method is to try to understand the Carian forms internally first and afterwards seek possible etymological explanations within a Luwic framework.

ardybyrs', the genitive of ardubur-, is the most transparent name of the group as it corre-

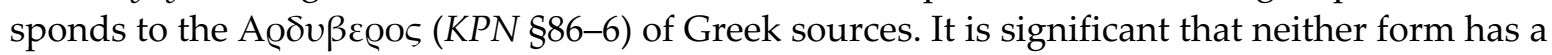
letter of nasal value. Adiego (2007: 333, 353) maintains the possibility of segmenting ard-ybyr- / A@ $\delta-v \beta \varepsilon \varrho o \varsigma$ based on the existence of a Carian name ybrs- at Hyllarima (C.Hy 1); at the same time, he compares tentatively the string $\alpha \varrho \delta-/ 0 \varrho \delta$ - of other Carian names in Greek transmission, but the analysis cannot be taken much farther. ${ }^{11}$

Three personal names from Thebes (Egypt), dtýbr, dýbr and kśatýbr, contain a string -ýbr; it is unclear whether $k u d t u b r$ is also related. This small set is very difficult to analyze. kśatýbr has been compared to the Lycian name $\Xi \alpha v \delta v \beta \varepsilon \rho ı \varsigma ~(K P N ~ § 1061)$, but Car. -t- is not usually rendered by Grk. $-v \delta$-. The problem is not insurmountable, ${ }^{12}$ but in $\$ 5$ we will see evidence that kśatýbr and $\Xi \alpha v \delta v \beta \varepsilon \varrho ı$ are to be separated. Thus, the easiest assumption is that the segmentable element in $d t y ́ b r$, dýbr and kśatýbr is the one they all share: $-y ́ b r$. This view is consistent with (1) the proposed segmentation of ard-ybyr-; (2) the existence of a self-standing Carian name ybrs-; (3) the fact that dýbr leaves little margin for different segmentations. ${ }^{13}$ In connection, I propose tentatively the segmentation of the latter name as $d-y ́ b r$, with a Luwic element $d-=$ I $\delta \alpha$ - that I will discuss in $\S 8)$.

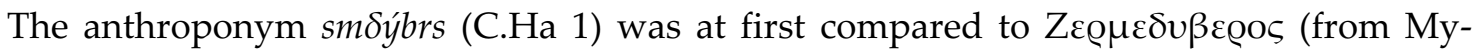
lasa) by Blümel (1990: 38-39), when the decipherment of Carian was not yet fully settled. Mel-

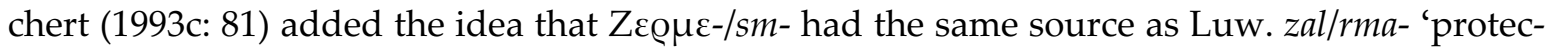
tion', because the "omission of the pre-consonantal /r/ in the Carian version" is supposedly unsurprising. This would point to ${ }^{*} s m$ - $\delta y$ brs. However, given the lack of secure cases of other similar omissions, I think it is actually unexpected (see Adiego 2007: 413). A second obstacle to segmenting ${ }^{*} s m$ - $\delta y$ brs is the use of the Carian letter $\delta$, usually matching Grk. $v \delta$, absent from the remaining names in the dossier. Conversely, if we opt for a different analysis of the name as * sm $\delta$-ýbrs it becomes possible to adduce acceptable comparanda for both elements. It is unclear whether the $-s$ of smónbrs is part of the stem (Adiego 2007: 283), but, if it was, then the

${ }^{10}$ Following Melchert (2003: 175-177, fn. 7), "Luwic" is used here to refer to a group of closely related dialects, including not just Luwian and Lycian, but also Carian, Pisidian, Sidetic (besides unattested dialects which left traces only in Greek-written onomastics). As Melchert notes, it remains an open question whether their affinity is due to a common origin in a unitary prehistoric language, to areal diffusion of innovations, or both. In any case, I use "Proto-Luwic" for reconstructions of (naturally hypothetical) proto-forms that could explain material shared by different Luwic dialects.

11 Schürr (2002) further compares $\alpha \varrho \delta$-/o@ $\delta$ - to the *(a)radu of two Late Bronze Age names from Arzawa, Tarhundarad $u$ and Piyammaradu, but the connection is hard to demonstrate as the meaning of the latter is uncertain.

12 There is so far no unchallengeable instance of the letter $\delta$ (the one systematically rendered by Grk. - $v \delta$-) in the Theban variety of the Carian alphabet (Adiego 2007: 222), so here $t$ could be taking its place. In any event, the subcorpus of Carian inscriptions from Thebes is still not well understood and $\delta$ might in the future be discovered to be a part of it as well.

${ }^{13}$ In the latter case, we might entertain the possibility that dýbr is a self-standing name itself, but this would leave the question of why would dtýbr and kśatýbr spell the same element with $t$, if $d$ was available at Thebes. 
second component is similar to the abovementioned self-standing name ybrs-. Concerning ${ }^{*} s m \delta$-, the possible term of comparison is the anthroponym I $\sigma \varepsilon \mu \varepsilon v \delta \alpha[\ldots]$ o $($ Caria; KPN §486), but I would further venture a connection with C. Luw. zamm(n)ant(i)- 'having zamna-.' This zamna- is a word of uncertain meaning but negative connotations that appears in Luwian onomastics of the $2^{\text {nd }}$ millennium BCE (see Melchert 1993a: 276 and Yakubovich 2013a: 101).

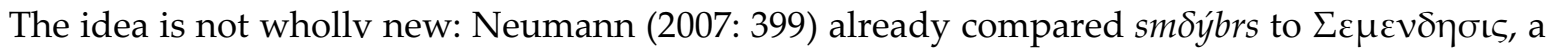
name from Cilicia (KPN §1396) that Houwink ten Cate (1961: 165-166) interpreted in the light of ${ }^{*} z a m n a-$. Still, Luwic ${ }^{*}$ zammant(i)-/tsammand(i)/ seems like a more straightforward source for ${ }^{*} s m \delta-.14$

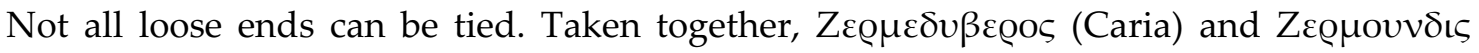
(Lycia; KPN §383) still point to the existence of ${ }^{*} Z \varepsilon \rho \mu(\varepsilon)$ - and ${ }^{*}-(\varepsilon) \delta v \beta \varepsilon \varrho o \zeta$. This is difficult to reconcile with the above scenarios, unless $Z \varepsilon Q \mu \varepsilon \delta$ - is some extended form of $Z \varepsilon Q \mu-$. Hence, at present an impeccable analysis of this set of Carian names is unfeasible, but I think it has been demonstrated how difficult, if not impossible, it is to associate them all with a virtual, variable element ${ }^{*}$-DUbr as I attempted previously. The above set of hypotheses, hinting at the isolation of -ybyr, -ýbr and -ýbrs (comparable to self-standing ybrs), is in my view the most economical.

Neumann (2007: 399) compared the Hellenized component * $v \beta \varepsilon Q(\iota)$ - in names from Lycia (see next section) and Caria with Luwo-Hitt. warri- 'helpful', warri- 'help' and warrai- 'to come in aid'. Are these Luwisms cognate with Car. ýbr-? One problem is the possibility (noted by Adiego 2007: 257) that Car. $y$ denoted a semivowel / $\mathrm{y} /$ (counterpart to $y=/ y /$ ), potentially the result of the fronting of $/ \mathrm{u}: /$ and $/ \mathrm{w} /$ in propitious environments. It is true that there is also evidence for Umlaut in Carian (cf. en 'mother' and ted 'father' < *anni- and *tádi-), which could have produced a front vowel and, as a consequence, motivated the fronting of $w$. However, the biggest difficult is that we would expect the development $y b r<{ }^{*} y \beta e r i<$ Pre-Carian *uweri, from P.-Luwic **uwar(r)i-, not from *warri-. The following section pursues these matters by dealing with Lycian and Cilician onomastics that contain an element potentially related to Car. -ybyr and -ýbr(s).

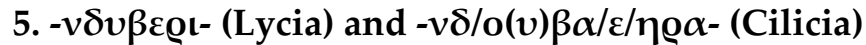

Above Car. kśatýbr was compared to $\Xi \alpha v \delta v \beta \varepsilon \varrho ı s$. This name needs to be treated as well, but its assessment cannot be separated from a set of other personal names from Lycian and Cilicia containing a similar component:

\section{Lycia:}

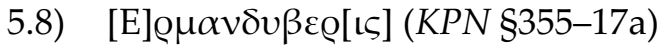

5.9) $\Xi \alpha v \delta v \beta \varepsilon \varrho เ \varsigma(K P N \S 1061)$

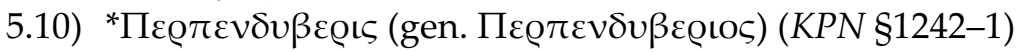

\section{Cilicia:}

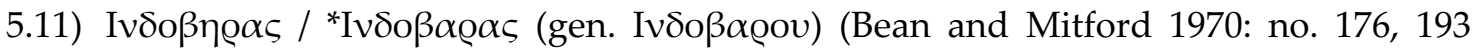
apud $P H I)$

5.12) $\underline{\text { M}} \underline{v} \delta v \beta \eta \varrho \alpha \varsigma$ (Bean and Mitford 1970: no. 180, 201 apud PHI)

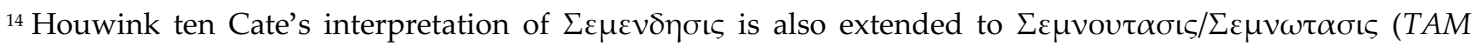

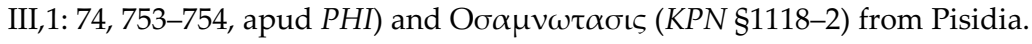




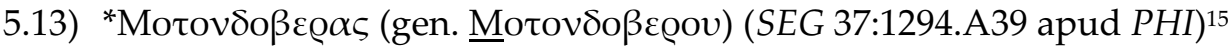

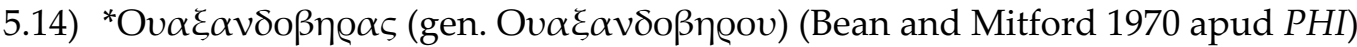

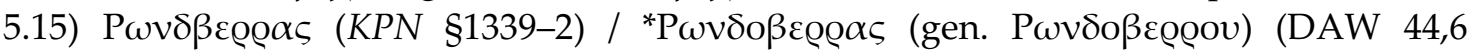
[1896] 71,155 apud $P H I)$

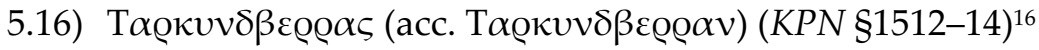

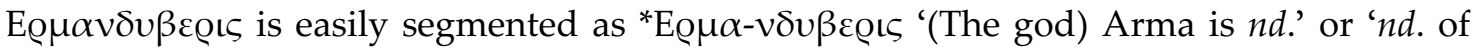

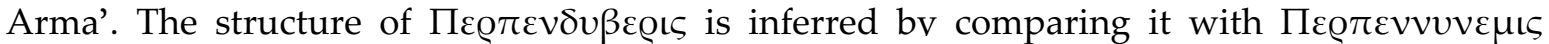

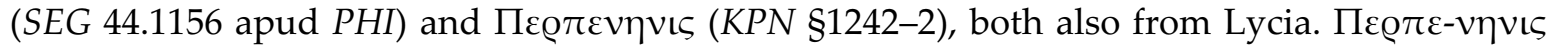
surely contains a reflex of Luwic *nani-, which traditionally is taken to be cognate with Luw. nāni- 'brother', but recently Oreshko (2014) argues for the existence of a homophonous Luwian word nani- 'lord, leader'. The name is structurally analogous to Lyc. Ermme-nẽne/i- $=$ EQ $\mu \varepsilon-$

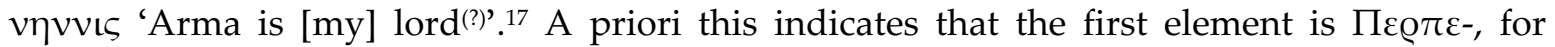
which we can compare Carian prp- in the personal name prp-wrik (see Adiego 2007: 402). ${ }^{18}$ The

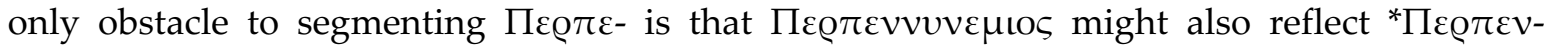

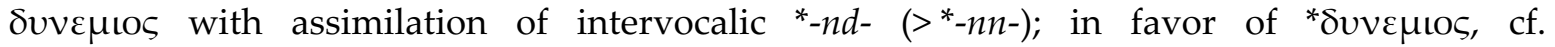

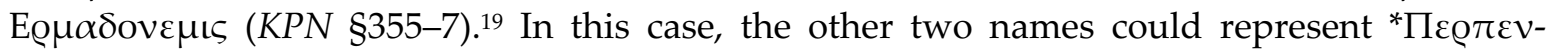
$\delta v \beta \varepsilon \varrho \iota \varsigma$ and ${ }^{*} \Pi \varepsilon Q \pi \varepsilon(v)$-v $\eta v \iota s$. Nevertheless, this is not a serious hindrance because ${ }^{*} \Pi \varepsilon \varrho \pi \varepsilon(v)-v \delta v \beta \varepsilon \varrho ı \varsigma$ is also possible.

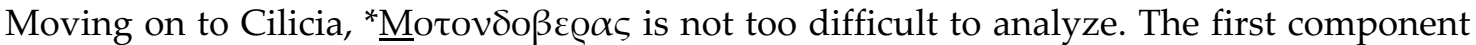

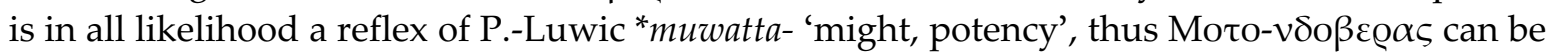
regarded as ' $n d$. of might' (or sim.). For the contraction of *muwatta- in Luwic onomastics of the ${ }^{1 s t}$ millennium BCE, cf. Lycian Mutlẽi vs. the Hittite royal name ${ }^{\mathrm{m} M u w a t a l l i-}=\mathrm{H}$. Luw.

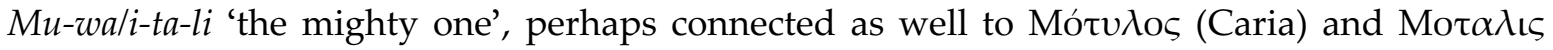
(Phrygia) (see Melchert 2013: 34, citing KPN §334 and Houwink ten Cate 1961: 103).

${ }^{*} \mathrm{O} v \alpha \xi \alpha \nu \delta \mathrm{o} \beta \eta \varrho \alpha \varsigma$ can be segmented as ${ }^{*} \mathrm{O} v \alpha \xi \alpha-\nu \delta \mathrm{o} \beta \eta \varrho \alpha \varsigma$ with relative security, since its first element is recognized in other Luwic names, particularly Car. $u / u ́ k s m u=\operatorname{Ov\alpha } \xi \alpha$ $\mu \mathrm{o} \alpha \varsigma / \mu \omega \varsigma$ (Isauria and Cilicia; KPN §1141, 2-3 and Adiego 2007: 427) '(having the might) of waksa' or '(having) waksa might' ${ }^{20}$ I would like to suggest that $\Xi \alpha v \delta v \beta \varepsilon \varrho ı$ is a reduced variant of ${ }^{*} \mathrm{O} v \alpha \xi \alpha v \delta v \beta \varepsilon \varrho เ \varsigma$, the probable Lycian version of ${ }^{*} \mathrm{O} v \alpha \xi \alpha \nu \delta o \beta \eta \varrho \alpha \varsigma .{ }^{21}$ This is further supported by the attestation of a $\Xi \alpha v \delta o \beta \varepsilon \varrho o \varsigma$ in Cilicia (Zgusta 1970: 35, apud Blümel 1992: 8). If

\footnotetext{
${ }^{15}$ Dagron and Feissel (1987: no. 11a). Based on the photograph provided the reading of M in this name seems plausible.

${ }^{16}$ It is uncertain to me whether M $\alpha v \delta o u \beta\llcorner 00 \varsigma(K P N \S 856-3)$ belongs in this group.

${ }^{17}$ For the latter, see Houwink ten Cate (1961: 144). Cf. the Hieroglyphic personal name LUNA.FRATER $2>$ Arma-nani? (Oreshko 2014: 618, citing Laroche 1966).

${ }^{18}$ Cf. also П $\alpha \varrho \pi о \lambda \iota v \gamma \iota \varsigma$ (Lycia; KPN §1208), which Schürr (2010: 191) directly compares to Car. prpwrik.

${ }^{19}$ Analyzed as *Arma-tuna+mi by Houwink ten Cate (1961: 134).

${ }^{20}$ The opaque ${ }^{*} \mathrm{ov} \alpha \xi \alpha$ - is attested in several other Anatolian anthroponyms from Greek sources. It is comparable to Milyan waxs(s)a-, which was translated as 'hero' by Gusmani. Melchert (2004: 134) disagrees, stating (without providing a justification) that waxssa- conveys an inanimate object. Shevoroshkin (apud Melchert 2004: 134) initially suggested 'heroic valor', but now tentatively reads 'fight(ers)' and compares Hitt. wah-nu- 'whirl' / wahessar 'swinging' (Shevoroshkin 2010: 165). A cognate of Milyan waxssa- is also found in the Lycian personal name Waxssepddimi.

${ }^{21}$ Notice, however, that the personal name $\Xi \alpha v \delta \alpha \varrho o ı \zeta \alpha \varsigma$ (Pamphylia) could in theory point to a different segmentation of $\Xi \alpha v \delta v \beta \varepsilon \rho ı \varsigma$, unless here we have an extended form *waksanda- > $\Xi \alpha v \delta \alpha-$. The Pamphylian name appears to be formed with *-อoı $\alpha$, analogous to $\mathrm{P} \omega(\mathrm{\iota}) \zeta \iota$ (Pisidia), which is a denasalized allomorph of P $\omega v \zeta \alpha$ $\left(<{ }^{*}[\right.$ K] runtiya-) 'Stag-god' (as seen by Melchert 2013: 36).
} 
this assessment is accepted, then we have to exclude any link to Car. kśatýbr, since the latter shows ś where $u / u ́ k s m u$ has s.

It is not instantly clear how is $\mathrm{P} \omega \nu \delta \beta \varepsilon \rho Q \alpha \varsigma /{ }^{*} \mathrm{P} \omega \nu \delta \mathrm{o} \beta \varepsilon \rho \mathrm{Q} \alpha \varsigma$ to be split. Without doubt, the first component is the name of the Stag-god * $(K)$ runtiya, but the latter surfaces variedly as P $\omega-$-,

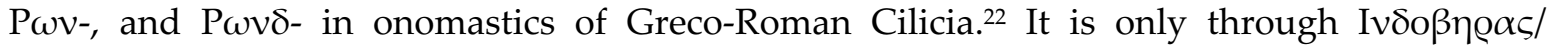
${ }^{*} \mathrm{I} \delta \delta \circ \beta \alpha \varrho \alpha \varsigma$ that we can shed some light on its structure. One needs only to draw a parallel with I $\alpha-\zeta \alpha \varrho \mu \alpha \varsigma$ '(Having the) protection of Iya' and P $\omega-\zeta \alpha \varrho \mu \alpha \varsigma$ '(Having the) protection of the Stag-god' (see Melchert 2013: 36, with refs.). In both cases we have pairs of theophoric names that interchange Runtiya and Iya, the Anatolian version of the Mesopotamian deity Ea. Combinatory analysis therefore hints at ${ }^{*} \mathrm{P} \omega(v)-v \delta(0) \beta \varepsilon Q \varrho \alpha \varsigma$ '(Having the) $n d$. of the Staggod' alongside a contracted ${ }^{*} \mathrm{I}(\alpha)$ - $\nu \delta o \beta \alpha / \eta \varrho \alpha \varsigma$ '(Having the) nd. of Iya'. Like P $\omega v \delta \beta \varepsilon \varrho \varrho \alpha \varsigma$, T $\alpha \varrho \kappa v \nu \delta \beta \varepsilon \varrho \varrho \alpha \varsigma$ is slightly ambiguous: should we segment ${ }^{*} \mathrm{~T} \alpha \varrho \kappa v \nu \delta-\beta \varepsilon \varrho \varrho \alpha \varsigma,{ }^{*} \mathrm{~T} \alpha \varrho \kappa v \nu-$ $\delta \beta \varepsilon Q \varrho ~ \alpha \varsigma$ or ${ }^{*} \mathrm{~T} \alpha \varrho \kappa v(v)-v \delta \beta \varepsilon \varrho \varrho \alpha \varsigma$ ? In light of all of the above, ${ }^{*} \mathrm{~T} \alpha \varrho \kappa v(v)-v \delta \beta \varepsilon Q \varrho \alpha \varsigma$ seems the most plausible composition, whence the likely meaning '(Having the) $n d$. of the Storm-god (Tarhunt)'. ${ }^{23}$

By now, it has become clear that $-v \delta v \beta \varepsilon \rho-\sim-v \delta o / v \beta \alpha / \varepsilon / \eta \varrho \alpha-$ denotes an attribute of the same kind as 'might' and 'protection', one that defined individuals and was considered a gift of the gods. It is also evident that its various spellings in Cilicia diverge from the Lycian version as regards the ending. This divergence suggests that the Cilician forms reflect a Luwic $a$ stem, while the Lycian variant conceals an $i$-stem whose ending moreover prompted the typical Lycian Umlaut. Thus: Cil. */ndoßæra-/ vs. Lyc. */ndoßari-/ >/ndoßæri-/.

At least formally, ${ }^{*}-v \delta v \beta \varepsilon Q-/{ }^{n} \mathrm{~d} \mho \beta æ r i-/$ is a direct match for Lyc. ntuweri-, the noun that underlies the substantivized plural adjective ñtuweriha (ñtuweri-ha), attested in one of the Lycian inscriptions on the Pillar of Xanthos (T44b: 57): ...se dewẽ: zxxaza: se ñtuweriha: ade: 'and made a dedication(?) to the warriors and to the $\tilde{n} t . '{ }^{\prime}{ }^{24}$ In this inscription, context demands a descriptive of people, possibly an occupational term or collective title, and since we are dealing with a substantivized adjective (- $h a$ is an adjective suffix), it seems self-evident that the ñtuwerihe are those who possess, belong, or are related to ñtuweri-, which might therefore be an attribute, as is - $v \delta v \beta \varepsilon \varrho-$. The lack of further examples makes it very difficult to unveil the exact meaning of the word, but we have seen in the previous section that Neumann compared Lycian ${ }^{*}-v \beta \varepsilon \varrho$ to Hitt. warri- 'help; helpful' and H. Luw. wariya- 'to help'. If we follow his idea, a possible etymology involves analyzing $\tilde{n}$ tuweri- as ${ }^{*} \tilde{n} t(e)-(u) w e r i$, with Lyc. $\tilde{n} t e-$ 'in(side)' and a reflex of Luwic *(u)wari- 'help', which in turn leads to the possibility of its meaning being 'assistance' or similar. ${ }^{25}$ This hypothesis admittedly rests on no independent evidence, but

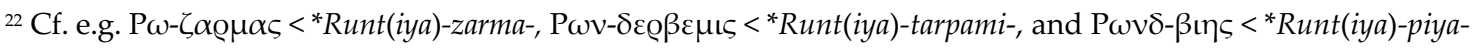
(see KPN, Melchert 2013: 43 and the interpretations in this section).

${ }^{23}$ Alternatively, it is possible that T $\alpha \varrho \kappa v v \delta \beta \varepsilon \varrho \varrho \alpha \varsigma$ reflect *Tarhunt-warri 'help to Tarhunt'? (Or 'from Tarhunt?') Cf. H. Luw. TONITRUS-hu-wa/i+ra/i-i /Tarhu-warra/i-/ (Hawkins 2000: 192, 534, 537, apud Melchert 2013: 38). If so, a similar explanation is also conceivable for P $\omega \nu \delta-\beta \varepsilon \varrho \varrho \alpha \varsigma$, but not for the other forms.

${ }^{24}$ Against this equation one could raise a priori the objection that intervocalic Greek - $\beta$ - normally renders Lyc. $-\mathrm{VbV}$ - rather than $-\mathrm{V} w \mathrm{~V}$ - (cf. Pubieleje $>\Pi v \beta \mathrm{t} \alpha \lambda \eta$ and $x \tilde{n}$ tabura $=\mathrm{K} \varepsilon v \delta \alpha \beta$ og $\alpha$ vs. $x u w a t a-j e=$ Ko $\alpha \tau \alpha)$. Yet there is evidence for some oscillation between $/ \beta /$ and $/ \mathrm{w} /$ in Lycian and related dialects. Thus Lycian has $x \tilde{n} t a w a$ 'to rule' and $x \tilde{n}$ tawata 'rule, kingship' but Milyan features both $x \tilde{n} t a b a$ - 'regulate' $>x \tilde{n} t a b a i m e / i-$ 'ruling' and $x \tilde{n} t a w a z a-$ 'rule' (Melchert 2004: 84, 136). Likewise, a cognate of Lyc. $x \tilde{n} t a w a t(i)$ surfaces as the personal name $\Gamma \delta \varepsilon \beta \varepsilon \tau \iota \varsigma$ in Pis-

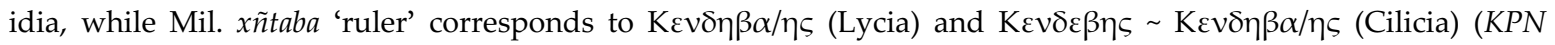
$\S 576-5)$.

${ }^{25}$ Melchert (pers. comm.) brings my attention to the Hittite verbal phrase anda warrissa- 'to come to the aid' found in KBo 5.8 i 18-20: ŠA LÚ.MEŠ URUTaggašta=ma kuiēš ÉRIN.MEŠ NARĀRE anda warriššanteš ešer n=at arha parāšeššer 
it would explain most facts in a satisfactory way. First, in the text in the Pillar of Xanthos it would lead to a plausible interpretation of the word in its context: dewẽ: zxxaza: se ñtuweriha "dedication(?) to the warriors/soldiers and the auxiliaries/auxiliary troops(?)". ${ }^{26}$ Second, the basic sense of 'assistance' would square well with the semantic structure of the personal names above. Specifically, we could have theophorics with varying divine attributes, such as $\mathrm{P} \omega-\zeta \alpha \varrho \mu \alpha \varsigma$ '(Having the) protection of the Stag-god' vs. P $\omega v \delta(\mathrm{o}) \beta \varepsilon \varrho \varrho \alpha \varsigma$ '(Having the) assis-

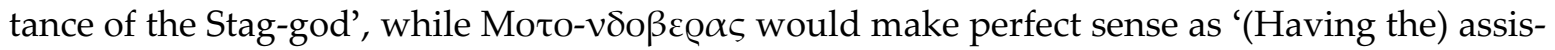
tance of might'.

The etymology of $-v \delta v \beta \varepsilon \varrho L^{-} \sim-v \delta o / v \beta \alpha / \varepsilon / \eta \varrho \alpha-$ must remain hypothetical, but my main contention is that combinatorial analysis favors their segmentation as such. Therefore, they are not likely to be directly related to the Carian names with ýbr- (although they may share a common element), nor do they contain a virtual *-tapara 'ruler', as Houwink ten Cate proposed for $\mathrm{P} \omega \nu \delta(\mathrm{o}) \beta \varepsilon \mathrm{Q} \alpha \varsigma$ (sic) and T $\alpha \varrho \kappa v \nu \delta \beta \varepsilon \mathrm{Q} \alpha \varsigma$. In conclusion, the Anatolian names discussed in the last two sections must be separated from LA $d u-p u_{2}-r e$.

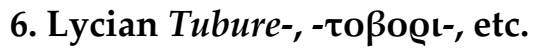

It is unclear whether Lyc. Tubure- in TL 69,2 (from Kyaneai) is another personal name or a sort of title (see Melchert 2004: 105).27 Milyan features a noun tuburi-, attested in plural, which tips scales in favor of the latter option.

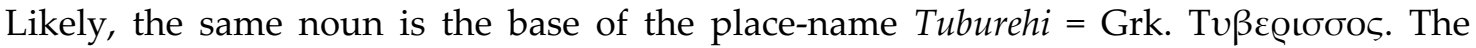
Greek form must have been adopted from a third language (Carian?) or from a pre-Lycian form that had not undergone the well-known Lycian shift ${ }^{*}>h$. Thus, from a Lycian viewpoint, Tuburehi would mean 'of/belonging to Tubur(e)'. Yakubovich (apud Valério 2007: 5) made the suggestion that the Lycian personal name Tebursseli might be toponymic, built on

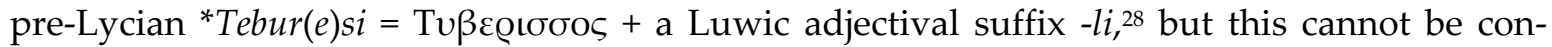
firmed.

Schürr (2012: 125) collects a possibly related form, the mythological name Tov $\beta \varepsilon \rho ı \varsigma$, from Stephen of Byzantium (s. v. " $\Upsilon \lambda \alpha \mu \mathrm{ol}$ ), and at the same time directs our attention to the per-

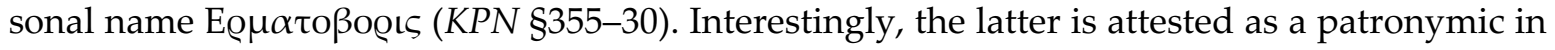

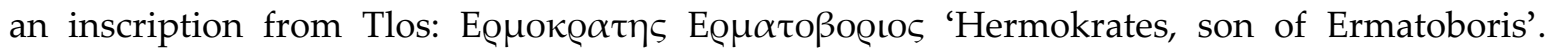
Colvin (2004: 62) has already suggested that this and other examples where father and son interchange Greek Hermes and the Anatolian Moon-god Arma as elements of their names point to an acknowledged (semantic) connection between the two, but this case opens the special

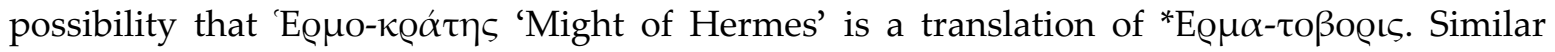

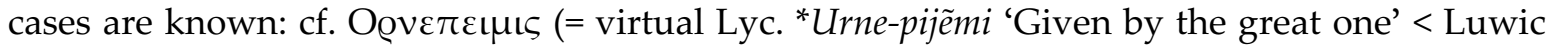

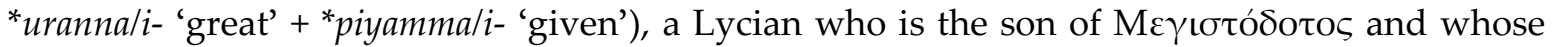

'But the auxiliary troops of Taggašta who had come to help (my opponents) dispersed' (Hoffner and Melchert 2008: 311). In my opinion, this Anatolian parallel gives some support to the hypothesis that Lyc. ñtuweri- is etymologically 'assistance, aid'.

${ }^{26}$ We might compare typologically the Roman auxiliarii (<Lat. auxilium 'help, assistance') and legiones adiutrices (< adjuvo 'to help'). The latter were "legions raised by the proconsul in the provinces for the purpose of strengthening the veteran army" (Lewis and Short 1891). Cf. also the Anatolian parallel in fn. 25.

27 The word is attested in the supposed genitive form Tubure $\diamond$ and accompanies the name of "Ipresida $\diamond$ son of Armpa $\diamond^{\prime \prime}$.

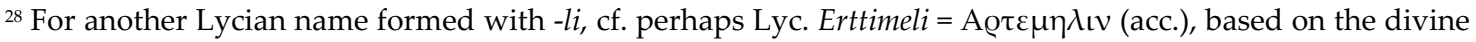
name Artemis (Melchert 2004: 94; 2013: 37). 
name seems to be the Lycian translation of his father's Greek name (see Colvin 2004: 69 for the names and Melchert 2013: 48 for the interpretation). However, the prospect that Lyc. tubure-

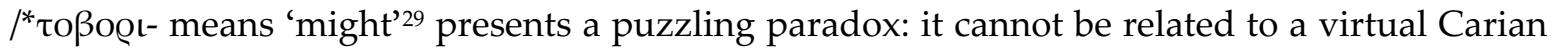
*-DUbr, but it seems clear from its vocalism that it also has no connection to a virtual Luw. *tapara- 'ruler', nor to the Lycian anthroponym (D)dapara (see the following sections). At best, tubure- ${ }^{*}$-toßo@t- could have a Carian equivalent in kudtubr (for which see $\S 4$ ). ${ }^{30}$

\section{Alleged Luwian *tapara 'ruler'}

Part of Yakubovich's (2002) dossier was drawn from Houwink ten Cate (1961: 158-159 following the work of Bossert), who compiled a small set of onomastic material he thought contained a Luwian noun *tapara 'ruler' (“or the like”), by comparison with Luw. tapar- 'to rule':31

7.1) dAlitapara ( ${ }^{\mathrm{d} A}$ A-li-ta-pa-ra) (KBo 5.1 i 10)

7.2) mPitta/ipara (mPí-it-ta/ti-pa-ra) (Laroche 1966: no. 1030)

7.3) mTiwatapara (mTi-wa-ta-pa-ra) (Laroche 1966: no. 1348)

7.4) ${ }^{\text {mTaprammi }(\mathrm{m} T a p-r a-a m-m i)}=$ Hieroglyphic LEPUS $+r a / i-m i^{32}$

Houwink ten Cate's view also requires revision. His inclusion of mPittapara and mTiwatapara relies on his idea that they present cases of haplology: thus *Pitta-tapara > Pittapara and *Tiwata-tapara > Tiwatapara. This claim is hindered by a number of obstacles. mPitta/ipara is the name of a Kaskaean rebel leader and therefore it is unlikely to have been Luwian. The name of another Kaskaean rebellious chief, mPittaggatalli, justifies a different segmentation, namely the isolation of Pitta- (cf. possibly Hittite pitta- 'allotment, gift'). This would yield as second component -para, which would also be feasible in the case of miwatapara < ${ }^{*}$ Tiwata-para, the name of a Hittite landholder. ${ }^{33}$ Luw. Tiwata 'Sun-god' as a self-standing onomastic element is grounded on H. Luw. SOLIS-wa-tà-muwa /Tiwatamuwa/ 'Tiwad is (my) might' (Laroche 1966: no. 1246). In any case, it should be noted that a segmentation as *Tiwa-tapara is in theory possible, given the existence of an anthroponym Tiwa-šarpa beside mdUTU-šar-pí ( ${ }^{*}$ Tiwata-šarpi?) (Laroche 1966: nos. 1344 and 1349). ${ }^{34}$

The divine name ${ }^{\mathrm{d}}$ Alitapara is a hapax in the Middle-Hittite Kizzuwatnaean ritual of Papanikri (KBo 5.1). It is more promising in the sense that Ali- might correspond to Luw. all(i)-

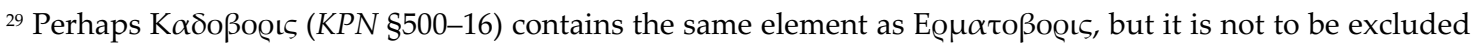
that this common component consisted only in the string ${ }^{*}$-oßo@ıs.

${ }^{30}$ Other names may belong in this dossier as well, but I suspect that only additional epigraphical data would

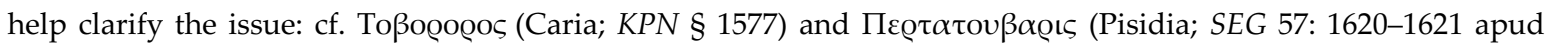
$P H I$ ) (see e.g. Blümel 1992: 23 and Schürr 2014).

${ }^{31}$ Houwink ten Cate also cites a divine-name *160-tapara, which is nowadays read as DEUS.VITIS-ti-PRAE-ia$={ }^{*}$ Tipariya-, presumably a wine-god (see Hawkins 2000: 97) and hence to be excluded.

32 See McMahon (1991: 53-54). This name appears in a biscriptal seal from Ugarit (RS 17.231), but also in the seal impression (Sob II 92) of a tablet from Boğazköy (KUB 25.32) and on Boğazköy socle 2.

33 See also Schuler (1965: 106-107). Melchert (forthcoming) has now argued that C. Luw. par(a)- means 'carry' $\left(<\right.$ PIE ${ }^{*} b^{h}$ er-). This would permit us to interpret tentatively miwata-para as 'Brought forth by Tiwat' on the same model as *Tarhu-piya 'Given by Tarhu(nt)' (for which see Melchert 2013: 47-48), while mPittalipara can perhaps,

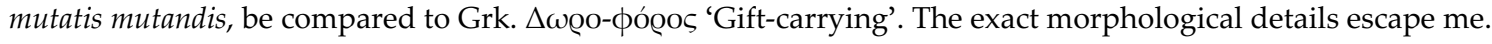

34 See Laroche (1966: nos. 1344 and 1349). 
'high'?,35 but, since it would now be our only genuine example of *-tapara in names, we should be cautious.

The personal name Taprammi was used by a high-ranking contemporary of king Tudhaliya IV. I suspect the least problematic way to analyze it is along the same lines as H. Luw. Pi-ha-mi (Melchert 2013: 34). The latter is cognate with C. Luw. piha(i)mma/i- 'imbued with splendor, resplendent', ${ }^{36}$ a denominative adjective constructed from the noun * piha- 'splendor' (see Melchert 1993a: 176). ${ }^{37}$ In our case, ${ }^{*}$ Taprammi would mean 'imbued with tapra-', which ironically can only be conciliated with *tapara if we assume some irregular syncope.

\section{Lycian Dapara}

Houwink ten Cate (1965: 118, 159) and Yakubovich (2002: 95-96; 2009b: 231) connect the alleged Luwian onomastic element *tapara- 'ruler'? to the Lycian personal name Dapara, which is rendered as $\Lambda \alpha \pi \alpha \varrho \alpha \varsigma$ in Greek in a Lycian bilingual inscription from Karmylessos (TL 6). ${ }^{38}$ As we will see (\$10), Yakubovich (2009b: 231) now proposes the source of both to be pre-Luw. *dabara- 'power' (vel. sim).

The first obstacle to this etymology, as noted by Yakubovich (2002: 96, n. 10) himself, is that the medial Grk. $\pi$ corresponds to Lyc. $-p-$, not $-b-$, thus indicating a voiceless bilabial stop that is inconsistent with the voiced sound of his Pre-Luw. *dabara- > Luw. *tapara-/tabara/.

The second obstacle lies in the interpretation of the initial dental. In synchronic terms, the equation Dapara $=\Lambda \alpha \pi \alpha \varrho \alpha \varsigma$ has been cited as proof of the widely accepted notion that Lyc. $d$ denotes a phoneme [ð]. This phonological interpretation is likely, but, based on other evidence (namely borrowings and the distribution of Lyc. $d$ and $t^{39}$ ), not on this pair. Paradoxically, it seems typologically strange that Lyc. [ð], a voiced non-sibilant coronal fricative, would cause a lambdacist spelling in Greek. In theory, Grk. $\delta$, which represented a voiced coronal stop /d/, would be the optimal choice for rendering [ð]; resorting to $\lambda=/ 1 /$ for a coronal fricative would seem to me justified only in the event that it had a lateral articulation, i.e. if it was pronounced at least some of the time as a lateral coronal fricative [b]..$^{40}$ Moreover, regardless of the precise pronunciation of $d$, it is obviously a Lycian sound. The very old theory that $d \sim \lambda$ indicate different strategies of rendering a special "substratum" sound (see e.g. Heubeck 1957) would only make sense if Lyc. Dapara and Grk. $\Lambda \alpha \pi \alpha \varrho \alpha \varsigma$ were independent transcriptions of a foreign

${ }^{35}$ Strauss (2006: 304) credits Hutter (with ref. to Zinko 1994: 76) with the interpretation of dAlitapara as a "Mischkompositum” from Hurr. allai- 'Herrin' and Luw. tapara 'Fluch', but the actual form of the latter is taparu'something evil' (Melchert 1993a: 207-208).

${ }^{36}$ Melchert (2013).

37 The noun * piha- is unattested but its existence is well-grounded on onomastics (ibid.).

${ }^{38}$ Neumann (2007: 36) cites three other examples of $\Lambda \alpha \pi \alpha \varrho \alpha \varsigma$ in Greek inscriptions (in Rhodes, Palaia Isauria

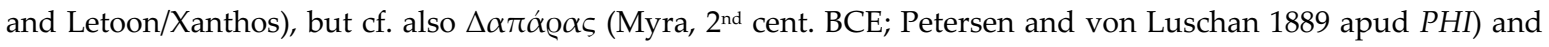

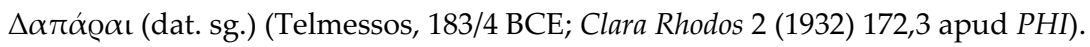

39 See Van den Hout (1995) and Melchert (2008: 49). On one hand, Iranian /d/ is transcribed with the digraph

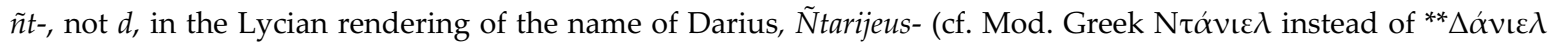
for Daniel, because $\delta=[ð]$ ). On the other hand, Iranian $\theta$ could be adapted as $d$, as seen in Lyc. xssadrapa-

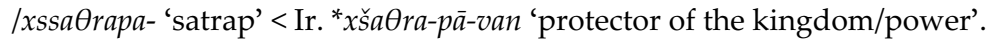

${ }^{40}$ This is the case of Amis, an Austronesian language of Taiwan, in which [క], [ð], [ð]], and [d] constitute different dialectal pronunciations of /ð/ (Maddieson and Wright 1995: 47). In fact, the articulation of [ろ] and [ð] is so close that these two sounds are not found to contrast in any language in the UPSID sample of 451 world languages (Maddieson 1984). 
name (with a foreign sound), from a third source. Since to my knowledge there is no evidence for a third, non-IE language in Lycia as late as the second half of the $1^{\text {st }}$ millennium BCE, this theory is unfounded. Most likely, Dapara is simply a Lycian name that was Hellenized in the bilingual and $\lambda$ the Greek rendering of Lyc. $d$. It is true that Lyc. $d$ is normally rendered with

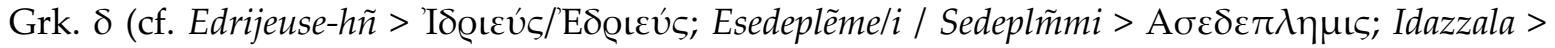

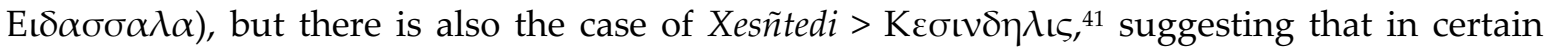
cases (allophonically?) Lyc. $d$ might have been pronounced as something other than a nonsibilant coronal fricative.

Two points that usually go unmentioned in discussions of Dapara are: 1) Lycian avoids word-initial $d$-; 2) when words beginning with geminate $d d$-follow a copulative $s e$, the two fuse and de-gemination takes place: cf. ddewẽ > se=dewẽ (see Melchert 2004: 9). Dapara too follows a copulative, se=dapara (ibid.: 92), so its actual self-standing form must be *Ddapara. This has implications for the etymology and pronunciation of the name. There is the possibility that Lyc. $d d \mathrm{~V}$ - reflects earlier ${ }^{*} \mathrm{~V} d \mathrm{~V}-$, and therefore I would like to suggest as a working hypothesis that ${ }^{*}$ Ddapara contains $I d a-$, a fairly common Luwic formant of names that appears in Hellenized transcriptions as $\mathrm{I} \delta(\alpha)-/ \mathrm{E} \mathrm{t} \delta(\alpha)$-. This suggestion finds a degree of support in Myl. $D d x u g[a]$, which, despite being damaged, invites a comparison with Car. dquq and Greekwritten I $\alpha \gamma \gamma \cup \gamma 0 \varsigma$ (as proposed tentatively by Adiego 1995: 27, n. 9). Notice that the segmentation of the Carian name as $d-q u q$ is independently supported by the existence of $q u q$ as a selfstanding name. The term of comparison is the abovementioned Lyc. Ida-zzala $>$ Eı $\delta \alpha-\sigma \sigma \alpha \lambda \alpha$, alongside Zzala $>\sum \alpha \lambda \alpha \varsigma$ (see Adiego 2007: 334). If this proposition is correct, what we have is *Idapara > Ddapara, with the same kind of (accent-driven?) aphaeresis seen in Mylian and Carian. Given the Lycian avoidance of initial $d$-, we would expect this consonant to undergo gemination after aphaeresis in order to keep up with the phonotactic demands of the language (Van den Hout 1995: 135).

Irrespective of the etymology of (se=)dapara, it seems that the $\lambda$ of $\Lambda \alpha \pi \alpha \varrho \alpha \varsigma$ renders the

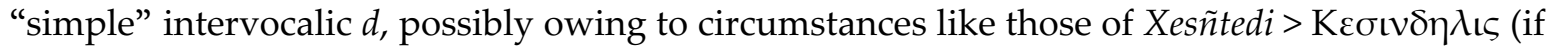
the latter is not the result of dissimilation). ${ }^{42}$ Just why intervocalic $d$ would be perceived as a close to a Greek lateral must remain a matter of speculation, ${ }^{43}$ but based on the present analysis I would keep Ddapara separated from *tapara-.

\section{Cilician $\mathrm{T} \beta \varepsilon \varrho \alpha / \eta-$}

Houwink ten Cate (1961: 159) analyzed as compounds with Luw. *tapara- four personal names from Hellenistic Cilicia: T $\beta \varepsilon \varrho \alpha \sigma \eta \tau \alpha \varsigma$ (*Tapara-zita/i), T $\beta \varepsilon \varrho \eta \mu \omega \sigma \iota \varsigma\left({ }^{*}\right.$ Tapara-muwa+zi), $\mathrm{P} \omega \nu \delta \beta \varepsilon \varrho \varrho \alpha \varsigma\left({ }^{*} R u(n)\right.$-tapara), and T $\alpha \varrho \kappa v v \delta \beta \varepsilon \varrho \varrho \alpha \varsigma\left({ }^{*}\right.$ Tarhu(nt)-tapara). The last two names were already treated in $\S 5$, so this section deals with the other two. The starting point is the combinatorial comparison with other Greek-written Anatolian anthroponyms:

${ }^{41}$ For all these onomastic forms see Melchert (2004).

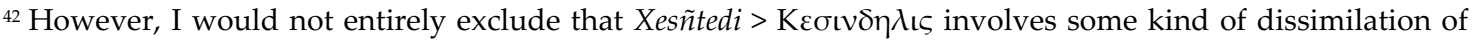
the voiced coronal fricative because of the preceding voiced coronal stop.

${ }^{43}$ I would at least annotate the possibility that, in this position and in fast-speech, the sound may have been flapped. A similar explanation could account for the match between the Carian place-name Mú $\lambda \alpha \sigma \alpha$ (Mylasa) and the Mutamutassa from cuneiform sources (via *Mudasa?) (see Carruba 1996: 23, apud Adiego 2007: 342), if the equation is valid. 


\begin{tabular}{|c|c|}
\hline $\begin{array}{l}\text { Т } \beta \varepsilon \varrho \eta-\mu \omega-\sigma ı \varsigma^{44} \\
\left({ }^{*} T .-m u w a-z i-\right) \\
\text { 'Man of } t \text {. might' }\end{array}$ & $\begin{array}{l}\mathrm{T} \beta \varepsilon \varrho \alpha-\sigma \eta \tau \alpha \varsigma^{45} \\
\left({ }^{*} T .-z i t a-\right) \\
\text { 'T. man' }\end{array}$ \\
\hline $\begin{array}{l}\text { Оле } \alpha-\mu \omega-\sigma \iota \varsigma / \text { O } \pi \varrho \alpha-\mu \rho v \alpha-\sigma \iota \varsigma^{46} \\
\left({ }^{*} \text { Uppara-muwa-zi-) }\right. \\
\text { 'Man of superior might' }\end{array}$ & $\begin{array}{l}\text { Ovт@ } \alpha-\sigma \eta \tau \alpha \varsigma^{47} \\
\left({ }^{*} \text { Uppara-zita-) }\right. \\
\text { 'Superior man' }\end{array}$ \\
\hline 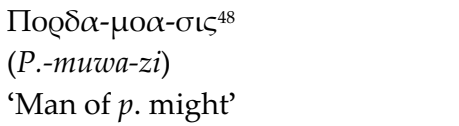 & 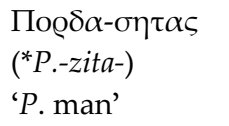 \\
\hline
\end{tabular}

The patterning of these names implies that $\mathrm{T} \beta \varepsilon \mathrm{Q} \alpha / \eta$ - is an adjective qualifying the named individual or his might. Possibly, it contains the PIE adjectival suffix -ro-, also seen in Luwic *uppara- 'superior' (<PIE *uperó-) (Melchert 2013: 44), but this is less than certain. A priori, *'Man with a ruler's might' or *'Ruler man' are acceptable meanings for T $\beta \varepsilon \varrho \eta \mu \omega \sigma \iota \varsigma$ and $\mathrm{T} \beta \varepsilon \mathrm{Q} \alpha \sigma \eta \tau \alpha \varsigma$, respectively. Besides clarifying the morphological and semantic structure, the above comparisons also supply us with phonological clues. By Hellenistic times Luwic *uppara (VCVRV) has been ubiquitously reduced to O(v) $\pi \mathrm{\rho} \alpha$ - (VCRV) in the onomastics of Lycia, Pamphylia, Isauria and Cilicia, probably through accent-driven syncope. ${ }^{49}$ If we transport these observations to our case, it seems expectable that *tapara- would resurface not as $\mathrm{T} \beta \varepsilon \mathrm{Q} \alpha / \eta-$, but rather as ${ }^{* *} \mathrm{TV} \beta \mathrm{O} \alpha-$, in Hellenistic Cilician onomastics. Even if we started with

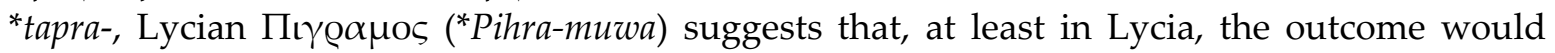
have been ${ }^{* *} \mathrm{TV} \beta \mathrm{Q} \alpha-$. It stands to reason that $\mathrm{T} \beta \varepsilon \mathrm{Q} \alpha / \eta$ - must reflect something else.

The key is the cluster T $\beta$-. A survey of late Greek-written Anatolian onomastics in PHI reveals that it is very rare:

\begin{tabular}{|c|c|c|}
\hline Region & Anthroponym & Reference \\
\hline Caria & 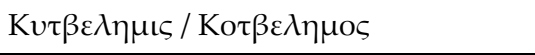 & KPN §771 / Myl 12.14 apud Blümel (1992) \\
\hline Caria & $[\mathrm{K}] v \alpha \tau \beta \eta \varsigma$ (acc. Kv $\alpha \tau \beta \eta v)$ & $K P N \S 765$ \\
\hline Caria & $\Sigma \alpha \gamma \gamma \mathrm{o \tau} \beta \eta \eta \varrho ı$ & Myl 12.3 apud Blümel (1992) \\
\hline Pisidia & $\mathrm{T} \beta \eta \mu \eta \varsigma$ / *T $\beta \eta \mu \iota \varsigma$ (in patr. T $\beta \eta \mu \varepsilon о \cup \varsigma$ ) & KPN §1522 \\
\hline Cilicia & ${ }^{*} \mathrm{~T} \beta \omega \tau-\varsigma$ (in patr. T $\beta \omega \tau о \varsigma$ ) & Bean-Mitford (1970: 185,205, apud PHI) \\
\hline Cilicia & ${ }^{*} \mathrm{~T} \beta \mathrm{tos}$ (in patr. T $\beta \mathrm{\iota ov}$ ) & KPN §1523 \\
\hline Cilicia & ${ }^{*} \mathrm{~T} \beta \varepsilon \varrho \alpha \sigma \eta \tau \alpha \varsigma$ (in patr. T $\left.\beta \varepsilon \varrho \alpha \sigma \eta \tau \alpha\right)$ & $K P N \S 1521-2$ \\
\hline Cilicia & 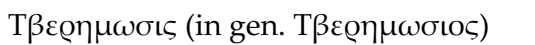 & $K P N \S 1521-1$ \\
\hline
\end{tabular}

${ }^{44}$ KPN §1521-2.

${ }^{45}$ KPN §1521-1.

${ }^{46}$ KPN §1099-4, 7.

${ }^{47}$ KPN §1099-11.

${ }^{48}$ Dagron and Feissel (1987: no. 11a). The reading given is Пo@ $\delta \alpha \mu o \alpha \underline{\varepsilon}$ เo (patronymic), but in my opinion,

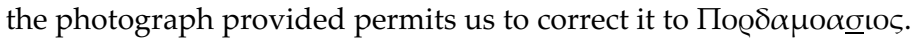

${ }^{49}$ Differently Pisidian Ov $\varepsilon \varepsilon Q^{-}$, now persuasively explained by Adiego (2012: 20) as a secondary development

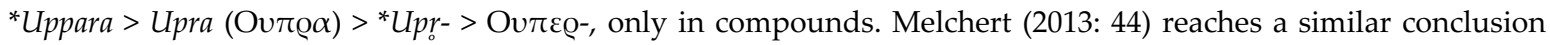
independently. It remains to be seen whether $\mathrm{O} \beta \mathrm{\rho} \alpha / \mathrm{l}$ - (seen e.g. in $\mathrm{O} \beta \mathrm{\rho} \alpha \sigma \eta \tau \alpha \varsigma$ ) belongs here. If it were so, we would probably have to assume a voicing of ${ }^{*} \mathrm{~V} p r \mathrm{~V}>-\mathrm{V} b r \mathrm{~V}$ - motivated by a prohibition of voiceless stops between a vowel and a sonorant in the underlying Luwic dialect(s). 
Let us put the evidence from Caria aside for a moment. Some of the names from Pisidia and Cilicia elicit comparisons with other anthroponyms that might help unveil the historical source of the cluster:

\begin{tabular}{|c|c|c|}
\hline $\mathrm{K} \beta-$ & $\mathrm{T} \beta-$ & Tov- \\
\hline LYC. K $\beta \alpha \iota \mu \iota^{50}$ & PIS. T $\beta \eta \mu \eta \varsigma /{ }^{*} \mathrm{~T} \beta \eta \mu \mathrm{s}$ & PIS. *Toun $\mu 1 \varsigma^{51}$ \\
\hline ISAUR. ${ }^{*} \mathrm{~K} \beta \mathrm{t} \alpha \varsigma^{52}$ & CIL. ${ }^{*} \mathrm{~T} \beta \mathrm{IO} \varsigma$ & \\
\hline LYC. K $\beta \alpha \delta \eta \varsigma^{53}$ & CIL. ${ }^{*} \mathrm{~T} \beta \omega \tau-\varsigma$ & \\
\hline
\end{tabular}

These potential correspondences suggest that $\tau \beta V$ from Pisidia and Cilicia can also appear in roughly the same area as $\tau o v \mathrm{~V}$, but matches $\kappa \beta \mathrm{V}$ from Lycia and Isauria. ${ }^{54}$ In this way, they evoke the different outcomes of P.-Anat. $d w \mathrm{~V}$ (or unstressed $d u w \mathrm{~V}$ ) in Lycian and Milyan. As is wellknown, Milyan features $t b \mathrm{~V}$, probably $/ \mathrm{t} \varphi \mathrm{V} /$, where Lycian has $k b \mathrm{~V}$, likely $/ \mathrm{c} \varphi \mathrm{V} /$ with a palatal stop: ${ }^{55} \mathrm{cf}$. Mil. tbisu vs. Lyc. kbihu 'twice' (<*dwisu-). ${ }^{66}$ In fact, among the personal names in the table, ${ }^{*} \mathrm{~K} \beta \mathrm{t} \alpha \varsigma /{ }^{*} \mathrm{~T} \beta \mathrm{to}$ can be compared to Lyc. kbije 'another, second' (<*dwiyo-) and probably means 'second-born child'. ${ }^{57}$ Further potential matches are possible if we take all this into consideration.

\begin{tabular}{|c|c|c|}
\hline $\mathrm{K} \beta-$ & $\mathrm{T} \beta-$ & Tou- \\
\hline LYC. K $\beta \alpha \iota \mu \operatorname{lo}^{58}$ & 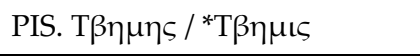 & 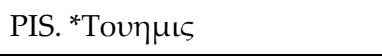 \\
\hline $\begin{array}{l}\text { ISAUR. }{ }^{*} \mathrm{~K} \beta \mathrm{t} \alpha \varsigma \text { (cf. Lyc. kbije } \\
\text { 'another; second') }\end{array}$ & CIL. ${ }^{*} \mathrm{~T} \beta \mathrm{tos}$ & \\
\hline LYC. K $\beta \alpha \delta \eta \varsigma$ & $\begin{array}{l}\text { CIL. }{ }^{*} \text { T } \beta \omega \tau-\varsigma \text { (cf. H. Luw. PN } \\
\text { Tu-waa/i-ti59 and Mil. Tuwad } a^{60} \text { ) }\end{array}$ & \\
\hline LYC. K $\beta \alpha-\mu \mathrm{o} \alpha \varsigma^{61}$ & & PIS. Tov $\alpha-\mu o v-\sigma ı \varsigma^{62}$ \\
\hline $\begin{array}{l}\text { Lyc. kbatra 'daughter' <*twatra } \\
<* \text { tuwatra }\end{array}$ & & $\begin{array}{l}\text { LYCAON. Tou } \alpha \tau \varrho ı \varsigma^{63} \\
<{ }^{*} \text { tuwatri(ya)- 'daughterly'? } \\
\text { (or 'little daughter'?) }\end{array}$ \\
\hline
\end{tabular}

${ }^{50} \mathrm{KPN} \S 562$.

${ }^{51}$ MAMA VIII 358 apud PHI.

${ }^{52} \mathrm{KPN} \S 563$.

${ }^{53}$ KPN §560. Cf. also Melchert (2004: 106).

${ }^{54}$ I follow Melchert (2013: 31) in his cautious note that assignment of Greek-transmitted names to specific Anatolian languages can be done only in variable degrees of assurance, hence my use of e.g. 'in/from Lycia' instead of 'Lycian'.

${ }^{55}$ Kloekhorst (2008a: 125). Melchert (2008: 49) speaks of a “front velar".

${ }^{56} \mathrm{It}$ is important to stress that if Lycian $k$ really represents a palatal stop /c/, then in theory it could also have been transcribed with $t$ in Greek. In this case, $\tau \beta$ would have been used for $/ c \varphi /$ as well. I thank Adiego (pers. comm.) for pointing this out.

${ }^{57}$ As suggested by Shevoroshkin (1978: 247). For a typological parallel cf. Latin numerical names Primus, Secundus, and so forth.

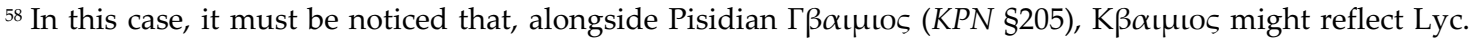
$x b a$ - instead of $k b a-$.

${ }^{59}$ Hawkins (2000: 308)

${ }^{60}$ Melchert (2004: 106).

${ }^{61} \mathrm{KPN} \S 563$.

${ }^{62}$ Brixhe et al. (1987: no. 26).

${ }^{63}$ KPN §1585-3. 
If this is correct, then names written with $\tau \beta \mathrm{V}$ in Caria ought to find a similar explana-

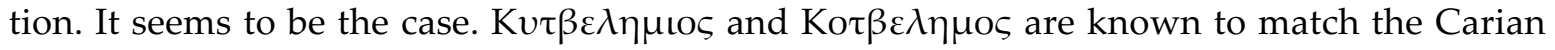
personal name qtblem- (Adiego 1993: 235; 2007: 408), but these seem moreover analogous to Mil. qetbeleimi- (as first seen by Shevoroshkin 1978: 252). Melchert (2004: 126) considers the latter to be an adjective (attested twice in plural), but attempts no translation. I would like to propose that both the Carian and the Mylian items go back to a Proto-Luwic participial adjective *Hwitwaläim(a/i)- 'vivified, animated' (or sim.). I base this on a hypothetical denominative verb ${ }^{*} H w i t w a l a \bar{i}$ - 'to make be alive, vivify', ultimately from a P.-Luwic adjective *Hwitwal(i)-, which survived in C. Luw. huitwal(i)- 'alive, living' (for the latter see Melchert 1993a: 84). ${ }^{64}$ I believe this etymology is not difficult to harmonize with current views on Mylian and Carian phonology ${ }^{65}$ and implicates a regular development P.-Anat. ${ }^{*} d w \mathrm{~V}>\mathrm{Car}$. / Mil. $t b \mathrm{~V}$.

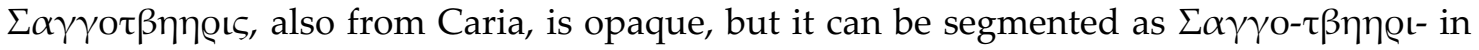
the light of $\Sigma \alpha \gamma \gamma \omega \varsigma$ (KPN §1369), another Greek-written Carian name. ${ }^{66}$ I will only note that this ${ }^{*} \tau \beta \eta \eta \varrho-$ might be cognate with Cilician $\mathrm{T} \beta \varepsilon \varrho \alpha / \eta$ - and that nothing a priori prevents it from having Proto-Luwic status. ${ }^{67}$

This digression reinforces the notion that $\tau \beta \mathrm{V}$ conceals etymological P.-Anat. ${ }^{*} d w \mathrm{~V}$, including instances from unstressed ${ }^{*} d u w \mathrm{~V}$. Thus Cilician $\mathrm{T} \beta \varepsilon \varrho \alpha / \eta$ - is not likely to derive from a virtual Luw. *tapara, but rather from a Proto-Anatolian adjective whose form is close to *d(u)wara-. Based on this reconstruction, I would like to suggest an Anatolian reflex of PIE

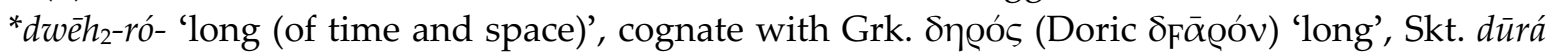

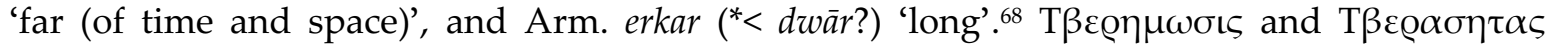
would make perfect sense as 'Man of long-lasting might' and 'Long-lasting man'. The immediate obstacle is that no direct descendant of P.-Anat. *dwāra- is attested among the Anatolian languages, but this absence is mitigated by the existence of the Hittite adverb tuwa 'far' (with

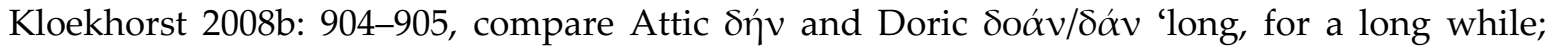
far') and the adjective tuwala- 'far' (see Tischler 1994: 486-489). We may add C. Luw. düwazza-, traditionally translated as 'wide', but now argued by Yakubovich (2013b: 163-164) to be an absolute superlative 'the most wide, broad'. The PIE etymon is thus well represented in Anatolia. In theory, if Luwian possessed an adjective *tuwala- 'far, long, wide' like Hittite, then it

${ }^{64}$ For C. Luw. huitwal(i)- 'alive, living', see Melchert 1993a: 84. For the etymology see Puhvel (1991: 354-355) and Kloekhorst (2008b: 355-356). More tentatively, P.-Luwic ${ }^{*} H w i t w a l(i)-$, if it ever was an $a$-stem, could also be the source of the personal name Kото $\beta \alpha \lambda \omega \varsigma$ (Caria; I. Amyzon 2.4), probably a match for Car. qtblo (see Adiego 2007:

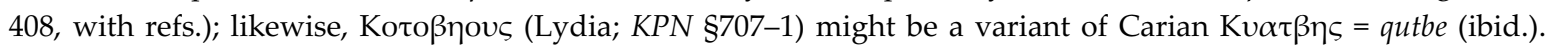
However, in these two cases the cluster $-t \beta \mathrm{V}$ - would appear broken with a labial vowel in the Greek transcription $(-\tau o \beta V-)$.

${ }^{65} \mathrm{Cf}$. the fate of the Storm-god's name: Lyc. $\operatorname{trqq\tilde {n}}$, Car. $\operatorname{trq} \delta$, Luw. Tarhunt- < P.Anat. *trH ${ }^{w}$ ant- (Kloekhorst 2008a: 138; see also Adiego 2007: 331-332). Mylian is written with the Lycian alphabet, so that Myl. $q$ should represent a sound close to that of Lyc. $q$, which according to Kloekhorst (2008a: 124-125) was a labialized velar $/ \mathrm{k}^{\mathrm{w}} /<$ P.-Anat. / $\mathrm{H}^{\mathrm{w}}$ :/. Car. $q$ is interpreted a possible uvular stop by Adiego (2007: 244) and as a labialized velar by Kloekhorst (2008a: 138).

${ }^{66}$ Attested in patronymic form: $\Sigma \alpha \gamma \gamma \omega \delta$ oऽ (see Blümel 1992: 21).

$67 *-\tau \beta \eta \eta \varrho t-$ is also reminiscent of Car. tbridbsś (at Memphis), possibly a papponym or appellative (Adiego

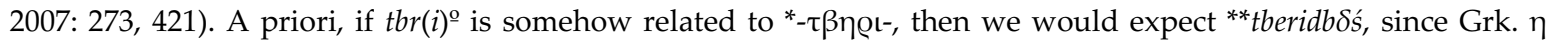
systematically reflects Car. e (Adiego 2007: 236). However, it cannot be excluded that in tbridbSś some sort of vowel reduction took place because of stress (I thank Adiego for pointing this out to me in a pers. comm.).

${ }^{68}$ For the PIE root and derivatives, see Mallory and Adams (1997: 356-357; 2006: 298-299); for the Armenian etymology see Martirosyan (2010: 266-267). 
might have undergone the characteristic "flapping" $l>r$, as well as syncope, thereby yielding a form *tuwara- that would explain our Cilician T $\beta \varepsilon Q \alpha / \eta-$.

Regardless of the future of this hypothesis, ${ }^{69}$ the point to be retained is that T $\beta \varepsilon \rho \eta \mu \omega \sigma \mathrm{s}$ and T $\beta \varepsilon Q \alpha \sigma \eta \tau \alpha \varsigma$ are unlikely to contain a reflex of *tapara 'ruler'.

\section{Hittite l/tabarna- and Luwian (:)tapar- 'to rule'}

It is well known that $l /$ tabarna- was used as a title by Hittite monarchs since the Old Hittite period and was apparently the personal name of at least one early king. Almost all rulers of Hatti down to the fall of Hattusa bore it, the exceptions being Suppiluliuma I and his immediate successors (Soysal 2005: 189-190). This has elicited the comparison with the case of Roman Caesar (> German Kaiser 'Emperor'; Russian царь 'Czar'), which began as a cognomen and evolved to an imperial title (Tischler 1988: 348-349). According to the CHD (L-N: 43), the distribution of the lexeme in Hittite "seems to confirm the theory that labarna or tabarna" was initially a personal name borne by an early ruler, but afterwards became the traditional title of the king of Hatti as a means of establishing a dynastic link with the ancestral Labarna. Besides Hittite, l/tabarna- appears in Hattic, Akkadian, Palaic, Luwian, and possibly Hurrian (see Soysal 2005 for a useful list of the attestations of the word). Hittite uses both spellings, but the remaining languages all spell the word exclusively with $t a-$, with the exception of Luwian, in which only the variant with $l a$ - is attested..$^{70} \mathrm{~A}$ detailed account of the myriad of attempts to etymologize l/tabarna- in the Hittitological literature would make this survey too long, so I will focus only on those with ramifications for the present discussion. ${ }^{71}$

Non-IE etymologies of $l /$ tabarna- include the hypothesis of a Hattic loanword in the IE Anatolian languages (among others, see recently Soysal 2005 and Kassian 2009-2010: 357-362), but no proposal has ever brought forth a full explanation of its meaning and morphology in acceptable Hattic terms. ${ }^{72}$ Of course, on its own this does not prove that the word is not Hattic.

Credit is due to Carruba (1986: 203f, apud Melchert 2003a: 18) for demonstrating that the $t$-/l- orthographic alternation, peculiar to the Hittite spellings of the title, has no parallel in the various Hattic borrowings in Hittite. Starting from the consensus that Proto-Anatolian * $d$ was devoiced to $t$ word-initially in Hittite and Luwian, Melchert (2003a: 18-19) has suggested an alternative account. He argues that if devoicing occurred first in "pre-Hittite", then a hypothetical "pre-Luwian" form *dabarna- would have been borrowed into pre-Hittite as labarna-, with /1/ as a substitute for "foreign" word-initial /d/. To account for all facts, he further postulates (following an idea by Tischler) that Hitt. labarna- "was later (but still prehistorically) altered to tabarna- by association with the Luwo-Hitt. verb tapar(r)iya)- 'to rule'," when the devoicing of initial ${ }^{*} d$ had already taken place in the latter language. Contrary to certain claims, Melchert's hypothesis is typologically sound. It finds support in Lydian, which borrowed the

${ }^{69}$ Melchert (pers. comm.) suggests as alternative comparandum Lyc. tuwere/i. I think that this is formally tempting and worth mentioning as a possibility, but the sense is unclear and, in my opinion, the suggested meaning 'celebrant' (or sim.), or person "responsible for prescribed offerings" (see Melchert 2004: 74, with refs.) would not square well with the semantics we expect for T $\beta \varepsilon \varrho \eta \mu \omega \sigma \iota \varsigma / T \beta \varepsilon \varrho \alpha \sigma \eta \tau \alpha \varsigma$.

${ }^{70}$ The primacy of labarna- in Luwian seems to have lasted beyond the Empire period, as early $1^{\text {st }}$ millennium Assyrian texts (see RIMA 3) mention Lubarna, the name (or title?) of a king of Pattin/Unqu.

${ }^{71}$ A relatively recent summary from the beginnings of the discipline onward is given in Soysal (2005: fn. 7), but cf. also Tischler (1991: 34, 116-119) and CHD L-N: 43.

72 Thus Soysal (2005), for example, interprets the title as a half-obscure $t a=p a r=n a$ 'the thousand na' without being able to explain the alleged morpheme -na. 


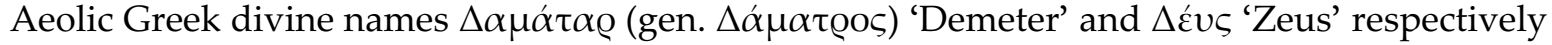
as lamẽtru and lefś/lewś. Apparently, Lydian prohibited the voiced coronal stop in initial position (Melchert 2003b: 181, fn. 13; Yakubovich 2005: 87, n. 50). Accordingly, Lyd. $d$, which can occur at the beginning of words, is thought to represent a coronal fricative /ð/, while actual [d] would have existed only as an allophone of $/ t /$ in certain environments (thus being spelled with $t$ ), but not word-initially (Melchert 2008: 58-59). The use of Lyd. /1-/ as the optimal replacement for Grk. /d-/ is not without parallels in contemporary languages. ${ }^{73}$ The main issue with Melchert's hypothesis is that it requires demonstration that the devoicing of initial stops is a post-Proto-Anatolian development that took place separately in Hittite and Luwian.

Whatever the phonological explanation, if labarna- was the original form, then it is tempting to think it was later changed to tabarna- by folk etymology, under the influence of tapar(r)iya- 'rule, authority'. If this is the case, it seems more likely that it was contaminated in its usage as a royal title. There are facts that mitigate both in favor and against this notion, but it would be beyond the scope of this paper to review them in detail. ${ }^{44}$ What is significant for our current purposes is the distinct possibility that the $t$-/l- alternation is not the reflex of different Hittite strategies to spell a special sound of a non-IE word from some ad hoc linguistic adstrate, such as a voiceless lateral affricate $/ \mathrm{t} t / 75$ or a voiced coronal fricative $/ ð /$. Together with the above analyses of $\lambda \alpha \beta u$ oıv $\theta$ o $\varsigma$ and Dapara/ $\Lambda \alpha \pi \alpha \varrho \alpha \varsigma$, this makes it even more difficult to maintain LA $d u-p u_{2}-r e$ and Hittite l/tabarna- as manifestations of the same contact word.

As hinted above, Hittite and Luwian possess an array of lexemes routinely involved in attempts to etymologize l/tabarna-. Their revision is not of secondary importance, as we are trying to determine whether they can all be connected to a traveling contact word associated with kingship. The most original forms appear to be Luw. (:)tapar- 'to rule' and Luwo-Hitt. tapar(r)iya- 'order, ruling; authority', which yields denominative verb tapar(r)iya(i)- 'to order, rule' (geminated -rr- is secondary; see Kloekhorst 2008b: 830). The last two have cognates in H. Luwian: LEPUS+ra/i-ia-76 or *tapariya- 'authority' and ("LIGNUM".)LEPUS+ra/i-(ia-) or *tapari(ya)- 'to decree, govern, with its reduplicated form *tatapari(ya)-. I would also include here the C. Luwian noun taparamman- 'ruling, governing' which on the model of āhra- 'pain,

${ }^{73}$ For instance, Yaqui (a Uto-Aztecan language of NW Mexico) replaced foreign [d] with either [r] or [1] in Spanish loanwords: cf. Yaqui lios < Sp. dios 'god' (Estrada Fernández 2009: 834, 844-846). The deployment of [1] as substitute for a dental stop is unsurprising, since lateral approximants are routinely articulated with an occlusion — the defining feature of stops — in the dental/alveolar region (Ladefoged and Maddieson 1996: 182-183). The preference for [l] over [t] (the voiceless dental/alveolar stop) as a substitute is also acceptable if we assume that in [d] the feature of voicing was perceptually favored by native speakers of Lydian.

${ }^{74}$ Yakubovich (2009b: 230) objects that altering the king's title would have constituted an unacceptable case of laesio majestatis. This is not an issue if we assume the contamination operated in Luwian after it borrowed Hitt. labarna: foreignisms are often opaque and thus more liable to folk etymology. English has a ready parallel in sovereign (<Mid. Eng. souerain < Old Fr. soverain 'princely, chief' < Late Lat. *super-ānus 'chief, highest'), an opaque Gallicism altered under influence of the unrelated reign (< Lat. regnare 'to have royal power, rule') (Skeat 1993 [1884]: 479 and Fowler et al. 2011 [1911]: 834). I know of no record of an English monarch feeling offended after being referred to as sovereign. The problem is that we would have to assume that tabarna- emerged in Luwian (where it left no traces) and then was re-borrowed into Hittite when Luwian had already become a prestige language.

75 The idea of a "/tl/" sound is as early as Forrer (1922: 183, n. 1) and has often been repeated in the literature (e.g. Tischler 1988: 350). For the explicit proposal of /tt/ see e.g. Kloekhorst (2008b: 521).

${ }^{76}$ The reading of the logogram LEPUS as *tapa- is well-established, but its motivation remains obscure. Different attempts to connect a hypothetical Luw. *tap $(p) a$ - 'hare' to Latin lepus or Armenian napastak (dialectal lapustrak, labastag) have, all of them, problems (see e.g. Arbeitman 1988: 77 and Katz 2001: 216 apud Yakubovich 2002: 98). In fact, by comparison with Massiliot Grk. $\lambda \varepsilon \beta \eta$ ¡í, Lat. lepus, -oris might be a borrowing from a non-IE western European language (see de Vaan 2008: 335). 
woe' > āhramman- 'state of pain' (see Melchert 1993a: 4-5) points to a noun *tapara- 'rule'. These words have a number of secondary derivatives in both Hittite and Luwian. ${ }^{77}$

Although all members of this group seem interrelated, it is not easy to explain them as derivatives from a single common source. The main issue is the difficulty to associate C. Luw. tapar- 'to rule' with Luwo-Hitt. tapar(r)iya- 'rule, authority' morphologically, despite obvious semantic ties. For Oettinger (1979: 384, apud Starke 1990: 259-260), the athematic stem of taparis structurally atypical of PIE-inherited verbal forms in Luwian, whence he concludes it most likely is of secondary origin. This idea was followed by Starke (ibid.), who argued that taparwas back-formed from Luw. tapar(r)iya(i)- 'to rule' (which in turn is a denominative verb from the noun tapar(r)iya-) on the model of verbs like lawarr(iya)- 'destroy(?)', but his proposal faces serious morphological obstacles. ${ }^{78}$ Still, the notion that tapar- is a secondary form based on tapar(r)iya(i)- remains the most economical. ${ }^{79}$ According to Melchert (1997: 87-88), tapar- is a non-present stem back-formed from a present stem tapari(ya)-80 by analogy with Luwian pairs of unextended non-present vs. extended present, such as Luw. kup- / *kupiya- 'to plot, scheme' (cf. also Hitt. karuš-ten / karuššiye- 'to be silent'). If Melchert is correct, then both verbal stems ultimately go back to the noun tapariya-.

In the meantime, for l/tabarna- itself Melchert (1993b: 107; 1997: 87-88; 2003a: 19) suggests an IE etymology partially linked to attempts by several scholars (starting with Hrozný 1917, apud Tischler 1991: 118) of connecting Luw. tapar- to Latin faber 'artificer', ${ }^{81}$ Old Church Slavonic dobr-b 'good' and Middle High German tapfer 'massive, firm; brave'. He reconstructs a PIE adjective * $d^{h} a b\left({ }^{h}\right)$-ro-82 'capable' as the source of a virtual substantivized adjective *tapar'powerful', which in turn would have yielded tapar-iya- '(sphere of) command' through the adjectival suffix -iya- (cf. C. Luw. tummantiya- 'obedience' < tummant- 'ear, hearing'; Melchert 1990: 91). The semantic and morphological aspects of this scenario need a brief comment. Se-

${ }^{77}$ For the cuneiform material see Tischler (1991: 116), Melchert (1993a: 203) and Kloekhorst (2008: 829-830); for the forms in H. Luwian, see Hawkins (2000: 629-630). As regards the remaining Anatolian relatives, Hittite has the agent noun Lútapariyalli- 'commander' (<*tapariya-) and the gloss-wedge form (:)taparammahit- 'position of commanding', probably a Luwian borrowing derived from taparamman on the model of handawat(i)- 'king' > *handawatahit- 'kingdom'. H. Luwian also has the agent noun LEPUS+ra/i-ia-li- = *tapariyal(i)- 'governor' (= LuwoHitt. Lútapariyalli-), which produces the factitive verb LEPUS+ra/i-ia-la- = *tapariyala- 'to be/make governor', as well as LEPUS-pa+ra/i-hi- = *taparahit- '(position of) authority' (nom.-acc. sg.), which is independent from Luwo-Hitt. (:)taparamma-hit-, and the hapax LEPUS-RA/I-ta-na = *taparitan 'authority (acc. sg.)'? The latter is at first sight baffling, but I think Yakubovich's (pers. comm.) suggestion that it this a syncopated version of the noun *tapari(ya)ta'command' is compelling; the process would be analogous to that of Hitt. *piyatta- > pitta- 'allotment, gift' (see Puhvel 1979: 213).

${ }^{78}$ Starke's argument is that this verb's infinitive, lauwarruna, is identical with that of tapar-, taparuna (he also cites (:)palhā and its inf. palhuna, but according to Melchert 1993a: 164 there is no stem *palhiya- attested for this verb). This is complicated by the fact that the two verbs are conjugated with different stems in the Pret. $3^{\text {rd }}$ sg: (:)ta-pa-ar-ta ta-pár-ta vs. la-wa-ar-ri-it-ta (Melchert 1993a: 126, 207).

${ }^{79}$ For Kloekhorst (2008b: 831), tapar- could be from an IE source only if its stem was /tbar-/, from a root of the structure ${ }^{*} \mathrm{~Tb}\left({ }^{h}\right)$ er- (where $T=$ dental stop). However, he admits that if tapar- is IE he cannot offer plausible cognates and, more importantly, his treatment does not exclude back-formation as a way to account for its atypical structure.

${ }^{80}$ According to Melchert (1997: 87), seventeen out of eighteen attestations of (:)tapar- are non-presents.

${ }^{81}$ Armenian darbin 'smith' has since long been cited as a cognate of Lat. faber (Meillet 1894: 165, apud Schrijver 1991: 102), but Melchert (2003a: 19, fn. 18) rejects this on phonological grounds. Yakubovich (2002: 103, fn. 26, owing to a suggestion by Kassian; 2009: 267-268) proposes the Armenian word to be a borrowing from an Urartian cognate of Hurr. tabrinni- 'blacksmith'.

${ }^{82}$ For those skeptical about both ${ }^{*} a$ and ${ }^{*} b$ as PIE phonemes, this would naturally be ${ }^{*} d^{h} e b^{h}-r o-$. 
mantics are less problematic if with Melchert (pers. comm.) one assumes ${ }^{*} d^{h} a b\left({ }^{h}\right) r o$ - had a semantic range similar to that of German tüchtig 'capable; big; good', which can explain the diversification to Lat. faber 'artificer (skillful working with various materials)', OCS dobrz- 'good' and virtual Luw. *tapar- 'powerful', although MHG tapfer 'valiant' < 'heavy' (<P.-Germanic *dapra'heavy'; see Kroonen 2013: 89) remains difficult. But the real conundrum lies in morphology. In order to maintain the development PIE ${ }^{*} d^{h} a b\left({ }^{h}\right)$-ro- $>$ P. Anat. *dabro- > Luw. *tapar-, Melchert (1993b) needs to resort to his Anatolian "law of finals", according to which *Cro- would have regularly shifted to Car-. Yet this rule is not consensual and a possible counterexample is found in Hitt. gim(ma)ra- 'countryside, field' and C. Luw. im(ma)ra- 'open country' < PIE * $\hat{g}^{h}$ im-ro-. ${ }^{83}$ In addition, we have seen that C. Luw. taparamman- points to a noun *tapara- 'rule' which is also able to account for tapariya- $\left(<^{*} \operatorname{tapar}(a)-i y a-\right)$, but can hardly be the outcome of $\mathrm{PIE}^{*} d^{h} a b\left({ }^{h}\right)-r o-$, or, for that matter, reconciled with *tapra-, the presumable component of the name Taprammi.

Interestingly, Yakubovich (2009b: 216, n. 11; 231) now traces $l /$ tabarna- back to pre-Luw. *dabra- 'rule' and considers his earlier *dabara- as a secondary formation by analogy with the vocalism of *dabar-na. His revision, which is only secondarily concerned with the etymology of the word, ${ }^{84}$ is based on four Anatolian anthroponyms attested in the Old Assyrian sources of the early $2^{\text {nd }}$ millennium BCE: Šupilapra, Walapra, Wašatapra, and Watapra (spelled with sign DA/TÁ) ${ }^{85}$ In Yakubovich's opinion, Walapra and Watapra are variants of the same name and contain an independent element $l /$ tapra, corresponding to Luw. *dabra- 'rule'. The alternating spellings, much like l/tabarna-, would indicate hesitations in transcribing an early Luwian voiced ${ }^{*} d$ by speakers of Hittite. Some reservations must be expressed, however. First: while Šupilapra is probably Hittite, ${ }^{86}$ it is not clear if the remaining names are Hittite, Luwian, or something else (e.g. Hurrian). Second: it is not certain that lapra and tapra are correctly segmented and (should they be Hittite) represent a Luwian borrowing. In the case of *Wa-lapra/*Wa-tapra it is not obvious what would Wa- be, and Kassian (2009-2010: 358-359) duly notes that ${ }^{*}$ Wala-pra $/{ }^{*}$ Wata-pra are also possible segmentations. Third: we are dealing with early $2^{\text {nd }}$-millennium BCE texts written in the Old Assyrian language and script, which possesses unambiguous means of transcribing a voiced stop /d/; therefore, one would need to assume the scribes involved were not Assyrians, but Nesites working for the Assyrians and struggling to write Luwian onomastics with a foreign sound. Tempting as it is to posit preLuw. dabra- > tapra-, the evidence is not uncontroversial and, even if *dabra existed as a selfstanding element, there are no grounds to assume its meaning was 'rule'.

It is worthwhile pointing out that, regardless of which source one prefers, Melchert's or Yakubovich's, there is an explanation - if only theoretical - of how $l /$ tabarna- might have

\footnotetext{
${ }^{83}$ I find compelling the proposed connection with PIE * $\hat{g}^{h}$ eim- 'winter' (cf. Hitt. gimmant- 'winter'), whence ${ }^{*} \hat{g}^{h}$ im-ro- *'wintery (steppe)' > 'open country' (Benveniste apud Puhvel 1997: 179).

${ }^{84}$ It is only in a footnote that Yakubovich retrieves his 2002 suggestion that this and other (allegedly) related forms "may have a non-Indo-European, "Minoan" origin".

${ }^{85}$ Spellings of these names and texts where they appear (apud Yakubovich 2009b: Table 25): Šu-pì-lá-áp-ra (KUG 8.7, in Hecker 1966: 13); Wa-lá-áp-ra-a (TC 3 191.22, in Ulshöfer 1995: 316); Wa-ša-tap-ra (Kt 89/k 383 2, in Donbaz 1993: 134); Wa-tá-áp-ra (CCT 1 6c.13, in Eisser and Lewy 1930: 20).

86 Šupi-lapra seems to contain šuppi- 'pure', which in the texts of the imperial period occurs exclusively in Hittite. Zehnder (2010: 7) claims that šuppi- has no valid IE etymology. Nevertheless, in the Kärum-period it occurs in personal names with transparent Anatolian etymologies. Hence, mŠuppi-uman ('of the pure one') is formed through the addition of the well-known Hittite ethnic suffix; likewise, fŠuppi-nika ('sister of the pure one') contains the exclusively Nesite -nika. mŠuppi-hšu ('male offspring of the pure one') and mŠuppi-hšušar ('female offspring of the pure one') contain forms of *h(a)šu-, a noun comparable to H. Luw. (NEPOS)hasu- 'progeny, descendant' (for these cases see Melchert 2003a: 16-17, Yakubovich 2009b: 216-217 and Zehnder 2010: 278-279).
} 
been derived in Anatolian terms. It was formulated by Starke (1980-1983: 406) based on the parallel of C. Luw. im(ma)ra- 'open country' > *immar-na > dmmarn-iya '(deity) of the open country'. It works with Yakubovich's *dabra- if the vocalism of *dabarna- was the outcome of anaptyxis after the syllabification of interconsonantal /r/: pre-Luw. ${ }^{*} d a b r-n a->{ }^{*} d a b r n a->$ ${ }^{*}$ dabarna- $\rightarrow$ Hitt. labarna- .87 The same process can be hypothesized for Melchert's *dabar-, only more straightforwardly, as it would be unnecessary to posit anaptyxis after the addition of $-n a-$.

In the end, the question whether l/tabarna- is related to Luw. tapariya-, etc. remains open. I would insist that the original semantics of the title need not be linked to kingship if truly it is just the crystallized personal name of a memorable early Hittite monarch — again, we can compare the case of Roman Caesar, whose imperial connotations are secondary. ${ }^{88}$

\section{Concluding remarks}

As Kassian (2009-2010: 359) duly notes, the overarching problem with positing a MinoanAnatolian contact word is that we need to assume an adstrate lexeme that not only travelled through different regions (Aegean, south-central Anatolia, Cyprus) during a long time-span (from the early $2^{\text {nd }}$ to second half of the $1^{\text {st }}$ millennium BCE), but did so while maintaining at all times a stable coronal fricative [ð] that prompted similar spelling alternations in several languages and scripts of the ancient Eastern Mediterranean.

The foregoing has showed that while there are grounds to link LA $d u-p u_{2}-r e$ and Grk. $d a-p u(2)-r i-t o-/ \lambda \alpha \beta v ́$ @ıv $\theta o s$, there is no compelling way of connecting these Aegean forms to the Anatolian material, see the table on the next page.

Even if the interpretations put forward here are not always indisputable, the onomastics of $1^{\text {st }}$-millennium BCE southern Anatolia that we have scrutinized are more cogently explained as containing diverse elements of Luwic tradition, and none can be shown to contain a virtual form *tapara 'ruler' or a relative of Minoan $d u$ - $p u_{2}$-re. At the same time, a Phoenician rather than an Anatolian etymology can be advanced (or rather reestablished) for Labranios,

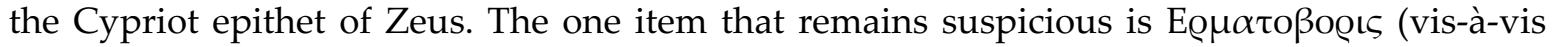

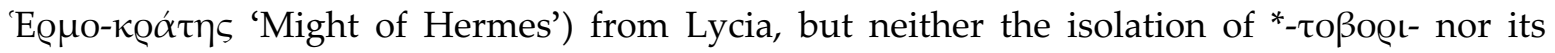

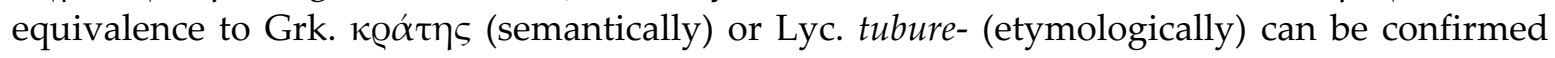
independently. Finally, not even the onomastics of the $2^{\text {nd }}$ millennium BCE have shown conclusive traces of *tapara 'ruler', but, somewhat paradoxically, a Luwian noun reconstructed with the same phonetic shape and a meaning close to 'rule' looks like the best way to account for Luw. tapariya- 'rule, authority' (>tapar(r)iya(i)- 'to rule' > tapar- 'to rule') and taparamman'ruling'. It remains unclear whether this noun would be related to the Hittite royal title l/tabarna- and, if it were, whether the relation is etymological (direct) or owes to folk etymology (indirect). This is the reason that virtual Luw. *tapara- 'rule' would now be the most promising item. Nevertheless, I see no compelling reason to associate it with LA $d u-p u_{2}-r e$, so I conclude there is no Anatolian link leading to the interpretation of the Minoan sequence as 'master'. It is to be seen whether the alternative 'cave that housed the cult of a local divinity', suggested by Sarullo (2008), can throw light on all instances of LA du-pu $u_{2}-r e$ and its Aegean relatives. This, however, must be left for another occasion.

\footnotetext{
${ }^{87}$ I thank Yakubovich for suggesting this development (pers. comm.).

${ }^{88}$ This holds true even if the explanation of Caesar as 'one delivered through a caesarian section' (< Lat. caeso 'to cut') by Pliny the Elder (Plin. Nat. 7.7. s. 9) is the product of folk etymology.
} 


\begin{tabular}{|c|c|c|}
\hline Region & Word(s) & Proposed etymology \\
\hline \multirow[b]{2}{*}{ Aegean } & LA $d u-p u_{2}-r e$ & Uncertain; 'cult cave'(?) (see Sarullo 2008) \\
\hline & LB $d a-p u\left({ }_{2}\right)-r i-t o-/$ Grk. $\lambda \alpha \beta u ́ \varrho ı v \theta o s$ & $\begin{array}{l}\text { Min. } d u-p u_{2}-r e / D ə P u ́ r(i)-/ \text { '?' + -v } \theta-\text { (see fn. 2) } \\
\text { 'underground complex'(?) }\end{array}$ \\
\hline \multirow{11}{*}{ Anatolia } & Hitt. l/tabarna- & 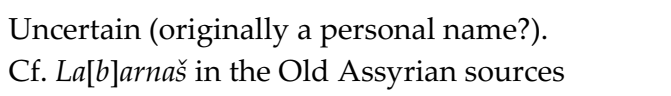 \\
\hline & $\begin{array}{l}\text { Luw. tapar(r)iya- 'rule, authority' } \\
\text { (>tapar(r)iya(i)- 'to rule' > tapar- 'to rule') and } \\
\text { taparamman- 'ruling' }\end{array}$ & Luw. noun *tapara- 'rule'(?), of uncertain origin \\
\hline & dAlitapara (Kizzuwatna) & Uncertain \\
\hline & *Taprammi & ${ }^{*}$ tapra- + adj. suffix -a(i)mmi- 'imbued with tapra-'(?) \\
\hline & $\begin{array}{l}-v \delta v \beta \varepsilon \rho \mathrm{Q}-(\mathrm{LYC} .) \\
-v \delta / \mathrm{o}(v) \beta \alpha / \varepsilon / \eta \rho \alpha-(\mathrm{CIL} .)\end{array}$ & $\begin{array}{l}\text { Comparable to Lyc. ñtuweri- '?'. } \\
\text { Perhaps Luwic anda + warri- > 'aid, assistance'(?) }\end{array}$ \\
\hline & Car. ybyr and ýbr(s) & Uncertain (related to Luwo-Hitt. warri- 'help'?) \\
\hline & $\begin{array}{l}\text { T } \beta \varepsilon \varrho \alpha / \eta-(C I L .) \\
{ }^{*} \tau \beta \eta \eta \varrho-(\text { CAR.) }\end{array}$ & P.-Anat. *dwāra- 'far, long'(?) \\
\hline & Lyc. ${ }^{*}$ Ddapara $($ se $=$ dapara $)$ & Luwic *Id(a)+(a)ppara (?) \\
\hline & Lyc. Tubure- & Uncertain \\
\hline & 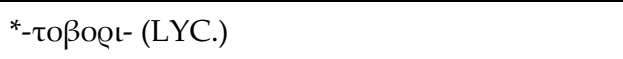 & A Lycian word for 'might'(??) \\
\hline & Labraunda (CAR.) & Uncertain \\
\hline Cyprus & Cypr. Grk. Labranios & $\begin{array}{l}\text { Phoen. lbnn /Labnān/ 'Lebanon' + Grk. adjective } \\
\text { suffix -ios }\end{array}$ \\
\hline
\end{tabular}

\section{References}

Adiego Lajara, Ignacio-Javier. 1993. Studia Carica. Investigaciones sobre la escritura y lengua carias, Barcelona.

1995. Contribuciones al desciframiento del cario. Kadmos 34, 18-34.

2007. The Carian Language. Leiden: Brill.

Arbeitman, Yoel L. 1988. Iranian “Scribe”, Anatolian “Ruler”, or Neither: A City's Rare Chances for "Leadership”. In Y. L. Arbeitman (ed.). Fucus. A Semitic/Afrasian Gathering in Remembrance of Albert Ehrman. Amsterdam/ Philadelphia: Benjamins, 1-101.

Bean, George E. and Mitford, Terence B. 1970. Journeys in Rough Cilicia 1964-1968, Etc. (Österreichische Akademie

Der Wissenschaften. Phil-Hist. Klasse. Denkschriften Band 102). Graz/Vienna/Colonia: Kommisionsverlag.

Billigmeier, Jon-Christian. 1989. The Linear A Libation Formula Revisited. American Philological Association: 121 Annual Meeting: Boston, Massachusetts, December 27-30, 1989: Abstracts. Atlanta: Scholars Press, 109.

Blümel, Wolfgang. 1990. Zwei neue Inschriften aus Mylasa aus der Zeit des Maussollos. Epigraphica Anatolica 16, 29-43.

1992. Einheimische Personennamen in griechischen Inschriften aus Karien. Epigraphica Anatolica 20, 7-34.

Brixhe, Claude, Drew-Bear, Thomas, and Kaya, Durmuş. 1987. Nouveaux monuments de Pisidie. Kadmos 26/2, 124-192.

Carruba, Onofrio. 1986. Tabarna: Chattisch oder Indogermanisch? IX. Turk Tarih Kongresi, Ankara, 21-25 eylül 1981. Kongreye Sunulan Bildiriler, 201-206.

- 1996. Neues zur Frühgeschichte Lykiens. In F. Blakolmer et al. (eds.), Fremde Zeiten. Festschrift für Jürgen Borchardt. Wien: Phoibos Verlag, 26-33. 
$C H D=$ Güterbock, H. G., Hoffner, H. A., and van den Hout Th. P. J. (eds.). 1983. The Hittite Dictionary of the Oriental Institute of the University of Chicago, Chicago.

Clara Rhodos 2 = Maiuri, Amedeo. 1932. Monumenti di scultura del Museo archeologico di Rodi I (Clara Rhodos. Studi e materiali pubblicati a cura dell' Istituto storico-archeologico di Rodi 2), Rhodes: Istituto storico-archeologico.

Colvin, Stephen. 2004. Names in Hellenistic and Roman Lycia. In S. Colvin (ed.), The Greco-Roman East: Politics, Culture, Society (Yale Classical Studies 31), Cambridge: Cambridge University Press, 44-84.

Dagron, Gilbert, and Feissel, Denis. 1987. Inscriptions de Cilicie. With the collaboration of Antoine Hermary, Jean Richard and Jean-Pierre Sodini. (Travaux et Mémoires du Centre de Recherche d'Histoire et Civilisation de Byzance. Collège de France. Monographies 4). Paris: De Boccard.

Davis, Brent 2013. "Syntax in Linear A: The Word-Order of the 'Libation Formula"'. Kadmos 52, 35-52. 2014. Minoan Stone Vessels with Linear A Inscriptions (Aegaeum 36). Leuven: Peeters.

De Hoz, Javier. 2004. De cómo los protogriegos crearon el griego y los pregriegos lo aprendieron. In P. Bádenas de la Peña et al. (eds.), Lenguas en contacto: El testimonio escrito. Madrid: Consejo Superior de Investigaciones Científicas, 35-56.

De Vaan, Michiel. 2008. Etymological Dictionary of Latin (and the other Italic Languages). Leiden: Brill.

Del Olmo Lete, Gregorio, and Sanmartín, Joaquín. 2003. A Dictionary of the Ugaritic Language in the Alphabetic Tradition. Translated by Wilfred G. E. Watson. Part 1 and 2. Leiden / Boston: Brill.

DocMyc $c^{2}=$ Ventris, Michael, and Chadwick, John. 1973. Documents in Mycenaean Greek, $2^{\text {nd }}$ ed. Cambridge: Cambridge University Press.

Donbaz, Veysel. 1993. Some Remarkable Contractors of 1-B Period Kültepe Tablets II. In M. Mellink et al. (eds.), Aspects of Art and Iconography: Anatolia and its Neighbors. Studies in Honor of Nimet Özŭuç. Ankara: Türk Tarih Kurumu. Pp. 131-54.

Duhoux, Yves. 1989. Le linéaire A: problèmes de déchiffrement. In Y. Duhoux, T.G. Palaima and J. Bennet (eds), Problems in Decipherment, Louvain-la-Neuve: Peeters, 59-119.

Egetmeyer, Markus. 2010. Le dialecte grec ancien de Chypre. Tome I: Grammaire; Tome II: Répertoire des inscriptions en syllabaire chypro-grec. Berlin/New York: De Gruyter.

Eichner, Heiner. 1975. Die Vorgeschichte des hethitischen Verbalsystems. In H. Rix (ed.), Flexion und Wortbildung. Akten der Fachtagung der Indogermanischen Gesellschaft, Regensburg, 9.-14. September 1973. Wiesbaden: Reichert, 71-103.

Eisser, Georg and Lewy, Julius. 1930. Die altassyrischen Rechtsurkunden von Kultepe. Mitteilungen der Vorderasiatisch-Ägyptichen Gessellschaft 33. Leipzig: J. C. Hinrichs.

Estrada Fernández, Zarina. 2009. Loanwords in Yaqui, a Uto-Aztecan language of Northwestern Mexico. In M. Haspelmath and U. Tadmor (eds.), Loanwords in the World's Languages: a Comparative Handbook. Berlin: De Gruyter, 823-845.

Evans, Arthur. 1921. The Palace of Minos at Knossos. Vol. I: The Neolithic and Early and Middle Minoan Ages. London: Macmillan and Co. Ltd.

Forrer, Emil. 1922. Die Inschriften und Sprachen des Hatti-Reiches. Zeitschrift der Deutschen Morgenländischen Gesellschaft 76, 174-269.

Fowler, Henry W., Fowler, Francis G. and Crystal, David. 2011 [1911]. The Concise Oxford Dictionary: The Classic First Edition. Oxford: Oxford University Press.

GORILA = Godart, Louis and Olivier, Jean-Pierre. 1976-1985. Recueil des inscriptions en linéaire A, 5 volumes, Paris: É. De Boccard.

Hall, Isaac H. 1885 [1883]. A Temple of Zeus Labranios in Cyprus. Journal of the American Oriental Society 11, clxviclxx.

Hawkins, John D. 2000. Corpus of Hieroglyphic Luwian Inscriptions. Volume I. Part I, II: Texts; Part III: Plates. Berlin/New York: W. de Gruyter.

Hecker, Karl. 1966. Die Keilschrifttexte der Universitatsbibliothek Giessen. Giessen: Universitatsbibliothek.

Heubeck, Alfred. 1957. Linear B und das 'aegaeische Substrat'. Minos 5, 149-153.

Hoffner, Harry A., and Melchert, Craig H. 2008. A Grammar of the Hittite Language. Vol. 1: A Reference Grammar. Winona Lake: Eisenbrauns.

Houwink ten Cate, Philo H. J. 1961. The Luwian Population Groups of Lycia and Cilicia Aspera during the Hellenistic Period. Leiden: Brill.

Kassian, Alexei. 2009-2010. Hattic as a Sino-Caucasic language. Ugarit-Forschungen 41, 309-447. 
Katz, Joshua T. 2001. Hittite ta-pa-ka-li-ya-aš. In O. Carruba and W. Meid (ed.), Anatolisch und Indogermanisch Anatolico e indoeuropeo: Akten des Kolloquiums der Indogermanische Gesellschaft 'Anatolio e indoeuropea' (Pavia 22.25. September 1998). Innsbruck: Institut für Sprachen und Literaturen der Universität Innsbruck, $205-237$.

Kloekhorst, Alwin. 2008a.Studies in Lycian and Carian Phonology and Morphology. Kadmos 47, 117-146.

2008b. Etymological Dictionary of the Hittite Inherited Lexicon. Leiden: Brill.

KPN = Zgusta, Ladislav. 1964. Kleinasiatische Personennamen, Prague: Tschechoslowakische Akademie der Wissenschaften.

Kretschmer, Paul. 1896. Einleitung in die Geschichte der Griechischen Sprache. Göttingen: Vandenhoed \& Ruprecht.

Kroonen, Guus. 2013. Etymological Dictionary of Proto-Germanic. Leiden: Brill.

Ladefoged, Peter and Maddieson, Ian. 1996. The Sounds of the World's Languages. Oxford: Blackwell.

Laroche, Emmanuel. 1966. Les noms des Hittites (Études linguistiques 4). Paris.

Lejeune, Michel. 1972. Phonétique historique du mycénien et du grec ancien. (2nd impression 1987). Paris: Éditions Klincksieck.

Lewis, Charlton T. and Short, Charles. 1891. A Latin Dictionary. Founded on Andrews' edition of Freund's Latin dictionary. revised, enlarged, and in great part rewritten by. Charlton T. Lewis, Ph.D. and. Charles Short, LL.D. Oxford: Clarendon Press.

Lipiński, Edward. 1995. Dieux et déesses de l’univers phénicien et punique (Studia Phoenicia 14). Leuven: Peeters.

Maddieson, Ian. 1984. UCLA Phonological Segment Inventory Database [Retrieved online: http://web.phonetik.unifrankfurtde/upsid.html].

Maddieson, Ian, and Wright, Richard. 1995. The vowels and consonants of Amis-a preliminary phonetic report. Fieldwork Studies of Targeted Languages III (UCLA Working Papers in Phonetics) 91, 45-65.

Mallory, James P. and Douglas Q. Adams (eds.). 1997. Encyclopedia of Indo-European Culture. London/Chicago: Fitzroy Dearborn Publishers.

Mallory, James P. and Douglas Q. Adams. 2006. The Oxford Introduction to Proto-Indo-European and the Proto-Indo-European World. Oxford: Oxford University Press.

MAMA VIII = Calder, William M. and Cormack, James M. R. 1962. Monuments from Lycaonia, the Pisido-Phrygian Borderland, Aphrodisias (Monumenta Asiae Minoris Antiqua 8). Manchester: University Press.

Martirosyan, Hrach K. 2010. Etymological Dictionary of the Armenian Inherited Lexicon. Leiden: Brill.

Masson, Olivier and Sznycer, Maurice. 1972. Recherches sur les Phéniciens à Chypre. Geneva and Paris: Droz.

Meillet, Antoine. 1894. Notes arméniennes III. Etymologies, Mémoires de la Société de Linguistique de Paris 8, $164-165$.

Melchert, H. Craig. 1990. Adjective Stems in *-iyo- in Anatolian. Historische Sprachforschung 103, $198-207$. 1993a. Cuneiform Luvian Lexicon. Chapel Hill: self-published.

1993b. A New Anatolian 'Law of Finals'. Journal of Ancient Civilizations 8, 105-113.

1993c. Remarks on Some New Readings in Carian. Kadmos 32, 77-86.

1997. Traces of a PIE Aspectual Contrast in Anatolian? Incontri Linguistici 20, 83-92.

2003a. Prehistory. In H. C. Melchert (ed.), The Luwians. Leiden: Brill, 8-26.

2003a. Language. In H. C. Melchert (ed.), The Luwians. Leiden: Brill, 170-210.

2004. A Dictionary of the Lycian Language. Ann Arbor: Beech Stave Press.

2008. Lycian. In R. D. Woodard (ed.), The Ancient Languages of Asia Minor, Cambridge: Cambridge University Press, 46-55.

2013. Naming Practices in Second and First Millennium Western Anatolia. In R. Parker (ed.) Personal Names in Ancient Anatolia (Proceedings of the British Academy 191). Oxford: Oxford University Press for the British Academy, 31-49.

Forthcoming. New Luvian Verb Etymologies. To appear in a Festschrift.

Mitford, Terence B. 1961. Further contributions to the epigraphy of Cyprus. American Journal of Archaeology 65, 93151.

Oettinger, Norbert. 1979. Die Stammbildung des hethitischen Verbums. Nürnberg: Hans Carl.

Ohnefalsch-Richter, Max H. 1893. Kypros, die Bibel und Homer. Berlin.

Oreshko, Rostislav. 2014. The Strange Case of Dr. FRATER and Mr. DOMINUS: a Re-Consideration of the Evidence Concerning Luwian nani-. In P. Taracha and M. Kapelus (eds.), Proceedings of the Eighth International Congress of Hittitology, Warsaw, 5-9 September 2011. Warsaw, 614-631.

Petersen, Eugen A. H., and von Luschan, Felix. 1889. Reisen im südwestlichen Kleinasien. Vol. II, Reisen in Lykien, Milyas und Kibyratis. Vienna. 
PHI = Packard Humanities Institute, The. 2012. Searchable Greek Inscriptions - A Scholarly Tool in Progress [http://epigraphy.packhum.org/inscriptions/main].

Puhvel, Jaan. 1979. Hittite words with initial pit/pát sign. In E. Neu and W. Meid, Hethitisch und Indogermanisch Vergleischende Studien zur historischen Grammatik und zur dialektgeographischen Stellung der indogermanischen Sprachgruppe Altkleinasiens, Innsbruck: Innsbrucker Beiträge zur Sprachwissenschaft, 209-217.

1991. Hittite Etymological Dictionary. Vol: 3: Words beginning with H. (Trends in Linguistics Documentation 5). Berlin/New York: Mouton de Gruyter.

1997. Hittite Etymological Dictionary. Vol: 4: Words beginning with K. (Trends in Linguistics Documentation 14). Berlin/New York: Mouton de Gruyter.

RIMA 3 = Grayson, A. Kirk. 1996. Assyrian Rulers of the Early First Millennium BC II (858-745 BCE). Toronto: University of Toronto Press.

Rüster, Christel and Wilhelm, Gernot. 2012. Landschenkungsurkunden hethitischer Könige. Wiesbaden: Harrassowitz. Sarullo, Giulia. 2008. The Cretan Labyrinth: Palace or Cave? Caerdroia 37, 31-40.

Schrijver, Peter. 1991. The Reflexes of the Proto-Indo-European Laryngeals in Latin. Amsterdam / Atlanta: Rodopi.

Schuler, Einar. 1965. Die Kaškäer: Ein Beitrag zur Ethnographie des alten Kleinasien. Berlin: Walter de Gruyter.

Schürr, Diether. 2002. Karische Parallelen zu zwei Arzawa-Namen. Kadmos 41, 163-167.

— 2010. Spätkarisch: Regionalisierung und Lautentwicklungen. In R. Van Bremen and J.-M. Carbon (eds.), Hellenistic Karia: Proceedings of the First International Conference on Hellenistic Karia, Oxford, 29 June-2 July 2006. Paris: Ausonius, 187-205.

- 2012. Lykische Genitive. Indogermanische Forschungen 115, 118-126.

- 2014. Lykische Orte und ihre Namen: drei Namentypen. In P. Taracha (ed.), with the assistance of M. Kepelus, Proceedings of the Eighth International Congress of Hittitology, Warsaw, 5-9 September 2011, Warsaw: Agade Publishing, 743-774.

SEG = Chaniotis, Angelos, Corsten, Thomas, Papazarkadas, Nikolaos, and Tybout, Rolf (eds.), Supplementum Epigraphicum Graecum. Leiden: Brill.

Shevoroshkin, Vitalij. 1978. Studies in Hittite-Luwian Names. Names 26, 231-257.

2010. Four Notes on Milyan. In T. M. Nikolaeva (ed.), Issledovanija po lingvistike i semiotike: sbornik statej $k$ jubileju Vjach. Vs. Ivanova (Studies in Linguistics and Semiotics: A Collection of Articles for the Anniversary for Vyacheslav V. Ivanov). Moscow: Languages of Slavonic Culture, 156-167.

Skeat, Walter W. 1993 [1884]. The Concise Dictionary of English Etymology. Ware: Wordsworth Editions Ltd.

Soysal, Oğuz. 2005. On the Origin of the Royal Title tabarna / labarna. Anatolica 31, 189-210.

Starke, Frank. 1980-1983. Labarna. Reallexikon der Assyriologie und vorderasiatischen Archäologie 6. Berlin.

1989. Untersuchungen zur Stammbildung des keilschrift-luwischen Nomens. StBoT 31. Wiesbaden: Harrassowitz.

Strauss, Rita. 2006. Reinigungsrituale aus Kizzuwatna: ein Beitrag zur Erforschung hethitischer Ritualtradition und Kulturgeschichte. Berlin: Walter de Gruyter.

Svantesson, Jan-Olof; Tsendina, Anna; Karlsson, Anastasia; and Franzén, Vivan. 2005. The Phonology of Mongolian. Oxford: University Press.

TAM III, 1 = Herbedey, Rudolf (ed.). 1941. Tituli Asiae Minoris, III. Tituli Pisidiae linguis Graeca et Latina conscripti, 1. Tituli Termessi et agri Termessensis, Vienna: A. Hoelder-Pichler-Tempsky.

Tischler, Johann. 1988. Labarna. In E. Neu, C. Rüster (eds.), Documentum Asia Minoris Antiqua. Festchrift für Heinrich Otten zum 75. Geburtstag, Wiesbaden: Harrassowitz, 347-358.

1991. Hethitisches etymologisches Glossar. Mit Beiträgen von Günter Neumann und Erich Neu. Teil III, L. 8, T, D/1. Innsbruck.

. 1994. Hethitisches etymologisches Glossar. Mit Beiträgen von Günter Neumann und Erich Neu. Teil III, L. 10, T, D/3. Innsbruck.

Thompson, Rupert J. E. 2005. Two notes on Mycenaean labial stops. Živa Antika 55, 107-115.

Ulshöfer, Andrea M. 1995. Die altassyrischen Privaturkunden. ATU 4. Stuttgart: Steiner.

Valério, Miguel. 2007. 'Diktaian Master': A Minoan Predecessor of Diktaian Zeus in Linear A? Kadmos 46, 3-14.

Ventris, Michael, and Chadwick, John. 1973. Documents in Mycenaean Greek, $2^{\text {nd }}$ ed. Cambridge: Cambridge University Press.

Yakubovich, Ilya. 2002. Labyrinth for Tyrants. Studia Linguarum 3 (Memoriae A.A. Korolev dicata). Ed. A. S. Kassian and A. V. Sidel'tsev. Moscow: Languages of Slavonic Culture, 93-116. 
2005. Lydian Etymological Notes. Historische Sprachforschung 118, 75-91.

. 2009a. Two Armenian Etymologies. Caucasian and Near Eastern Studies XIII, Tbilisi, 266-272.

. 2009b. Sociolinguistics of the Luvian Language. Leiden: Brill.

. 2013a. Anatolian Names in wiya- and the Structure of Empire Luwian Onomastics. In A. Mouton et al. (eds.), Luwian Identites: Culture, Language and Religion Between Anatolia and the Aegean. Leiden: Brill, 87-123.

. 2013b. The Degree of Comparison in Luwian. Indogermanische Forschungen 118, 155-168.

Younger, John G. 2011. A view from the sea. In: E. Hallager (gen. ed.), The seascape in Aegean Prehistory. Athens: The Danish Institute at Athens, 161-183.

Zehnder, Thomas. 2010. Die hethitischen Frauennamen: Katalog und Interpretation (Dresdner Beitrage zur Hethitologie 29). Wiesbaden: Harrassowitz.

Zinko, Christian. 1994. Die Hethiter: Volk zwischen indogermanischer Tradition und kleinasiatisch-autochthonen Einflüssen. Mitteilungen der Grazer Morgenländischen Gesellschaft 4, 54-82.

Zgusta, Ladislav. 1970. Neue Beiträge zur kleinasiatischen Anthroponymie (Dissertationes orientales 24). Prague: Academia.

Мигель Валерио. Аинейное А $d u-p u_{2}-r e$, хеттское tabarna и их гипотетические когнаты.

В статье подробно рассматривается и заново оценивается предположение о связи линейного А $d u-p u_{2}$-re и хеттского царского титула t/labarna-, а также целого ряда фонетически схожих апеллятивов с семантикой власти и могущества, топонимов и антропонимов, происходящих из Древней Анатолии. Автор отделяет от форм $d u-p u_{2}-r e$ и t/labarna- некоторые анатолийские ономастические единицы, относящиеся преимущественно к 1-му тыс. до н.э., предлагая для них независимую этимологию на основе языков лувической подгруппы. Также автор разделяет кипрский эпитет Зевса Labranios и хеттское Labarna-, защищая старую гипотезу о Labranios как об адаптации финикийского названия Диванского хребта. В результате тщательного пересмотра материала автор приходит к выводу, что, несмотря на возможное существование лувийского субстантива *tapara- 'власть', у нас нет независимых доводов ни в пользу связи минойского $d u-p u_{2}-r e$ с какими-либо формами из анатолийский языков, ни в пользу того, что $d u-p u_{2}$-re вообще значит 'господин' (или нечто близкое).

Ключевые слова: линейное письмо А, табарна, лабарна, лувические языки, анатолийская ономастика, киликийские имена. 